\begin{tabular}{lll}
\hline Missio Ecclesiae & \\
ISSN 2086-5368 (Print) & \\
ISSN 2086-5368 (Online) & INSTITUT \\
https://jurnal.i3batu.ac.id/index.php/me \\
Vol.9, No.2, pp. 66-97, 2020
\end{tabular}

\title{
Evaluasi Kinerja Dosen dalam Melaksanakan Pendidikan dan Pengajaran di Sekolah Tinggi Alkitab Jember Dengan Metode 360 Derajat
}

\author{
Nelly Nelly ${ }^{a}$, Dina Elisabeth Latumahina ${ }^{b}$ \\ ${ }^{a}$ Sekolah Tinggi Alkitab Jember, jbcnelly@yahoo.co.id \\ ${ }^{b}$ Institut Injil Indonesia, dina.latumahina@gmail.com
}

\begin{tabular}{|c|c|}
\hline INFO ARTIKEL & BSTRAK \\
\hline $\begin{array}{l}\text { Kata Kunci: } \\
\text { Evaluasi Kinerja } \\
\text { Dosen, Pendidikan } \\
\text { dan Pengajaran, } \\
360 \text { Derajat. } \\
--=-=--=- \\
\text { Keywords: } \\
\text { Lecturer } \\
\text { Performance } \\
\text { Evaluation, } \\
\text { Education and } \\
\text { Teaching, } 360 \\
\text { degree. } \\
---=--=-=-\end{array}$ & $\begin{array}{l}\text { Dosen merupakan salah satu komponen esensial dalam suatu sistem } \\
\text { pendidikan di perguruan tinggi. Dalam Tridharma Perguruan } \\
\text { Tinggi, dosen harus melakukan dengan beban kerja paling sedikit } \\
\text { sepadan dengan dua belas SKS dan paling banyak enam belas SKS } \\
\text { pada setiap semester sesuai dengan kualifikasi akademik. } \\
\text { Pelaksanaan tugas utama dosen ini perlu dievaluasi dan dilaporkan } \\
\text { secara periodik sebagai bentuk akuntabilitas kinerja dosen kepada } \\
\text { para pemangku kepentingan. Penilaian kinerja dosen dipandang } \\
\text { perlu dalam kaitannya dengan tercapainya Tridharma Perguruan } \\
\text { Tinggi. Evaluasi kinerja adalah penilaian yang dilakukan secara } \\
\text { sistematis untuk mengetahui hasil pekerjaan karyawan dan kinerja } \\
\text { organisasi. } \\
\text { Untuk mengetahui kinerja dosen dalam melaksanakan Tridharma } \\
\text { Perguruan Tinggi di STA Jember maka penelitian ini menggunakan } \\
\text { penelitian evaluasi, secara khusus evaluasi kinerja. Dalam } \\
\text { penelitian evaluasi kinerja ini, model yang digunakan adalah } \\
\text { evaluasi kinerja } 360 \text { derajat. Secara umum model evaluasi ini } \\
\text { bertujuan untuk mengukur apakah kinerja dosen sesuai dengan } \\
\text { standar atau kriteria kinerja yang sudah ditentukan. Penilaian } \\
\text { kinerja dosen tersebut dilakukan oleh multi penilai atau penilaian } \\
\text { dilakukan oleh beberapa orang. Data yang didapat dianalisis dan } \\
\text { dicari hubungannya, dibandingkan, kemudian menemukan pola } \\
\text { dasar dari data aslinya. Berdasarkan rekapan persentase rata-rata } \\
\text { skor ketercapaian dari tujuh belas orang dosen menunjukkan kinerja } \\
\text { dalam melaksanakan pendidikan dan pengajaran adalah baik, mulai } \\
\text { dari merencanakan, melaksanakan, dan mengevaluasi pembelajaran } \\
\text { serta disiplin dalam mengajar. Dalam hal karakter/ kepribadian } \\
\text { menunjukkan semua dosen baik yaitu kewibawaan sebagai dosen, } \\
\text { arif dalam mengambil keputusan, menjadi teladan dalam sikap dan }\end{array}$ \\
\hline
\end{tabular}


perilaku, mampu mengendalikan diri dalam berbagai situasi dan kondisi serta adil dalam memperlakukan mahasiswa.

\begin{abstract}
The lecturer is one of the essential components in the education system in higher education. In the Tridharma of Higher Education, lecturers must carry out a workload of at least twelve credits and a maximum of sixteen credits in each semester according to their academic qualifications. The implementation of this lecturer's main task needs to be evaluated and reported periodically as a form of accountability for lecturer performance to stakeholders. Performance appraisal is deemed necessary in its assessment by achieving the Tridharma of Higher Education. Company assessments are carried out systematically to see the results of employee work and organizational performance.

To see the performance of lecturers in the Tridharma of Higher Education at Jember Bible College to evaluate and evaluate performance. In this performance evaluation research, the model used is a 360-degree performance evaluation. In general, this evaluation model aims to measure whether the lecturer's performance is in accordance with the specified performance standards or criteria. The performance appraisal is carried out by multiple appraisers or the service is carried out by several people. The data obtained were analyzed and searched, compared, then found the basic pattern of the data built. Based on the recapitulation of the average percentage of achievement scores of seventeen lecturers, it shows that their performance in implementing education and teaching is good, starting from planning, implementing, and evaluating learning and teaching discipline. In terms of character/ personality, it shows that all lecturers are good, namely authority as lecturers, wise in making decisions, being role models in attitudes and behavior, being able to control themselves in various situations and conditions and fair in treating students.
\end{abstract}

\title{
PENDAHULUAN
}

Pendidikan adalah salah satu penggerak utama dari semua perubahan yang terjadi sepanjang sejarah di bawah kekuasaan Tuhan. Ketika pendidikan semakin maju maka dunia akan mengalami perubahan demi perubahan. Oleh karena itu, sudah sepatutnya dunia pendidikan mendapat perhatian yang sangat besar dalam kehidupan manusia.

Sekolah Tinggi Alkitab (STA) Jember merupakan salah satu Perguruan Tinggi Teologi/Agama Kristen (PTT/AK) di Jawa Timur. STA Jember menyelenggarakan Pendidikan Tinggi bagi warga gereja Kristen di Indonesia untuk ikut serta dalam usaha meneruskan, mengembangkan pelestarian dan pengolahan peradaban serta penerapan ilmu, teknologi dan seni dalam rangka membangun individu, masyarakat, bangsa dan negara serta umat manusia melalui pelaksanaan fungsi Tridharma Perguruan Tinggi, yaitu: Dharma Pendidikan, Dharma Penelitian dan Dharma Pengabdian kepada masyarakat. Dalam rangka pembentukan kepribadian, kegiatan pendidikan Sekolah Tinggi Alkitab Jember diarahkan 
kepada pengembangan manusia sebagai makhluk individu, makhluk sosial, makhluk susila dan makhluk yang beriman kepada Tuhan Yesus Kristus. Mengarahkan warga gereja yang terpanggil menjadi pelayan Injil agar memiliki motivasi yang murni dalam pelayanan, mengajar kebenaran Firman Allah secara murni sebagai bekal dalam pelayanan sehingga dapat memberikan jawaban atas tantangan zaman dan mendidik peserta didik untuk berkembang secara kreatif, dinamis dalam pelayanan dan tanggap akan kuasa Roh Kudus yang menjadi dasar dalam pelayanan. STA Jember mempunyai Visi: menjadi perguruan tinggi untuk pembentukan dan pengembangan teologi alkitabiah, kontekstual, berciri khas Pantekosta. Pembentukan pekerja gereja yang handal, memiliki kepakaran, daya cipta, terampil melayani dalam konteks masyarakat majemuk (Statuta STAJ, 2012).

Saat ini STA Jember terdiri dari tiga Program Studi: Strata Satu Teologi, Strata Satu Pendidikan Agama Kristen dan Strata Dua Magister Teologi. Masing-masing Prodi terdiri dari beberapa orang dosen tetap: Prodi Teologi lima dosen tetap; Prodi Pendidikan Agama Kristen, enam dosen tetap dan Prodi Magister Teologi, enam dosen tetap; jadi ada tujuh belas orang dosen tetap di STA Jember. Di antara dosen tetap tersebut ada empat orang yang telah mendapatkan sertifikasi dosen dan sepuluh orang yang memiliki Jabatan Fungsional.

Dosen adalah pendidik yang mempunyai tugas utama merencanakan dan melaksanakan proses pembelajaran, menilai hasil pembelajaran, melakukan pembimbingan dan pelatihan, serta melakukan penelitian dan pengabdian kepada masyarakat. Dosen yang diangkat memiliki kualifikasi sekurang-kurangnya lulusan strata dua (S2) untuk program sarjana dan lulusan program strata tiga (S3) atau sedang kuliah menyelesaikan strata tiga (S3) untuk pascasarjana. Dosen yang diangkat telah memiliki pengalaman kerja sebagai pendidik pada perguruan tinggi sekurang-kurangnya dua tahun, memiliki jabatan akademik sekurang-kurangnya asisten ahli dan memiliki atau sedang mengusahakan sertifikat pendidik di perguruan tinggi yang dikeluarkan oleh lembaga yang berwenang (Statuta STAJ, 2012).

Berdasarkan Statuta STA Jember, dalam melaksanakan perkuliahan, dosen wajib:

1. Membuat rancangan/desain mata kuliah berdasarkan tujuan mata kuliah yang tertera dalam kurikulum. Desain mata kuliah ini harus disetujui oleh tim akademik jurusan/program studi;

2. Membuat silabus berdasarkan desain mata kuliah yang sudah dibuat. Silabus ini harus disetujui oleh tim akademik jurusan/program studi;

3. Membagikan silabus kepada mahasiswa di awal perkuliahan;

4. Menjelaskan kepada mahasiswa tentang pentingnya integritas akademik serta hak dan kewajiban mahasiswa dalam mata kuliah tersebut;

5. Memberikan kuliah sesuai dengan silabus yang telah disepakati;

6. Mendidik mahasiswa untuk menjadi calon ilmuwan dengan standar mutu yang tinggi;

7. Mengevaluasi prestasi akademik mahasiswa secara obyektif dan fair;

8. Mengembalikan pekerjaan mahasiswa yang sudah dinilai kepada mahasiswa;

9. Membagikan kuesioner evaluasi cara mengajar dosen kepada mahasiswa pada hari terakhir kuliah, sebelum ujian akhir;

10. Menyerahkan nilai hasil evaluasi mahasiswa ke bagian administrasi akademik tepat pada waktunya;

11. Membuat evaluasi diri tentang kinerjanya sebagai dosen setiap tahun dan menyerahkannya kepada ketua jurusan/program studi;

12. Membaca hasil evaluasi mahasiswa dan memanfaatkan komentar mahasiswa dalam evaluasi tersebut untuk meningkatkan profesionalisme dirinya;

13. Merevisi desain mata kuliah dan silabus paling lama setiap dua tahun guna menampung perkembangan mutakhir di bidang ilmu dan/atau di bidang pembelajaran. 
Adapun pelaksanaan pendidikan dan pengajaran yang ada di STA Jember terangkum sebagai berikut:

Untuk pendidikan dan pengajaran terdapat tiga komponen yaitu merencanakan, melaksanakan proses pembelajaran serta menilai dan mengevaluasi hasil pembelajaran. Berdasarkan pengamatan awal, 52.94\% dosen menyerahkan Silabus, Satuan Acara Perkuliahan (SAP) dan Kontrak Perkuliahan sesuai waktu yang ditetapkan yaitu satu Minggu sebelum perkuliahan; ada kesesuaian materi ajar dengan kontrak perkuliahan dan SAP dilihat dari berita acara perkuliahan; belum semua dosen membuat bahan ajar berupa buku ajar, diktat dan handout; kehadiran dosen memberikan kuliah dalam satu semester masih ada beberapa yang tidak memenuhi target empat belas pertemuan; semua dosen melakukan pembimbingan tugas akhir berdasarkan SK Ketua STA Jember; pelaksanaan kegiatan pembimbingan akademik dilakukan oleh semua dosen dengan berpatokan pada panduan akademik yaitu mahasiswa konsultasi akademik sebanyak tiga kali pertemuan dalam satu semester: sebelum perkuliahan, sebelum UTS dan setelah UAS; para dosen sebagian besar menyerahkan soal ujian satu Minggu sebelum pelaksanaan ujian (UTS dan UAS), mutu soal ujian sesuai dengan SAP dan lebih bersifat kognitif sedangkan penyerahan nilai akhir hampir sebagian besar melewati batas waktu yang ditetapkan; untuk setiap Mata Kuliah yang diampu rata-rata mahasiswa mendapat nilai A dan B; Wakil Ketua I Bidang Akademik bersama Kaprodi, Dosen Pembimbing Akademik (atau Dosen Wali) dan Unit Penjamin Mutu (UPM) memonitor dan mengevaluasi proses pembelajaran berdasarkan pedoman akademik STA Jember; sebagian besar dosen melakukan kegiatan pengembangan diri untuk meningkatkan kompetensi melalui lembaga seperti AA dan Pekerti atau lainnya.

STA Jember selalu berupaya dalam peningkatan mutu internal secara berkelanjutan. Salah satu upaya yang sudah dilakukan adalah dengan melakukan penilaian terhadap kinerja dosen. Penilaian dilakukan setiap akhir semester dengan membagikan kuesioner penilaian kinerja dosen kepada mahasiswa. Proses penilaian tersebut masih dilakukan secara manual sehingga membutuhkan waktu pengolahan data yang sangat lama. Selain itu penilaian tersebut masih bersifat subjektif dan tidak relevan dengan keadaan yang sebenarnya sebab hanya mengevaluasi mengajar dosen dalam satu semester sedangkan untuk penelitian dan pengabdian kepada masyarakat belum dilakukan evaluasi, sehingga tidak dapat digunakan sebagai dasar pengambilan keputusan.

Dosen merupakan salah satu komponen esensial dalam suatu sistem pendidikan di perguruan tinggi. Sebagaimana diamanatkan dalam UU Nomor 14 Tahun 2005 tentang Guru dan Dosen, dosen dinyatakan sebagai pendidik profesional dan ilmuwan dengan tugas utama mentransformasikan, mengembangkan, dan menyebarluaskan ilmu pengetahuan, teknologi, dan seni melalui pendidikan, penelitian, dan pengabdian kepada masyarakat. Kompetensi dosen menentukan kualitas pelaksanaan Tridharma Perguruan Tinggi sebagaimana yang ditunjukkan dalam kegiatan profesional dosen. Dosen yang kompeten untuk melaksanakan tugasnya secara profesional adalah dosen yang memiliki kompetensi pedagogik, profesional, kepribadian dan sosial yang diperlukan dalam praktek pendidikan, penelitian, dan pengabdian kepada masyarakat (Harisantoso, 2018).

Sebagai unsur yang paling penting di Perguruan Tinggi, dosen juga dituntut untuk dapat berpartisipasi dalam tata pamong institusi dan pengembangan profesi. Hal ini cukup beralasan mengingat dosen merupakan pelaksana fungsi utama: pendidikan, penelitian, pengabdian pada masyarakat dan manajemen Perguruan Tinggi. Kelompok dosen lebih tinggi dari kelompok lainnya (mahasiswa, tenaga penunjang akademik, dan tenaga administrasi), karena memiliki jenjang pendidikan dan kemampuan akademik yang lebih tinggi dan merupakan kekuatan utama pada jurusan/fakultas maupun Universitas. Oleh karena itu pemberdayaan dosen merupakan suatu keharusan bagi universitas, karena dosen 
yang kompeten dan memiliki kinerja yang tinggi merupakan kunci keberhasilan Jurusan/ Fakultas/Universitas (Tim Penyusun Unissula, 2018).

Penilaian kinerja dosen dipandang perlu dalam kaitannya dengan tercapainya Tridharma Perguruan Tinggi. Penilaian kinerja, pada umumnya memiliki tiga tujuan utama, yaitu: (1) Tujuan administratif adalah untuk peningkatan gaji, promosi, pemberian penghargaan, pemutusan hubungan kerja; (2) Tujuan pengembangan karyawan berkaitan dengan konseling dan bimbingan, serta pelatihan dan pengembangan; dan (3) Tujuan strategis dari penilaian kinerja adalah untuk menilai apakah karakteristik, perilaku, dan hasil kerja karyawan mengarah pada pencapaian tujuan organisasi, mendiagnosa masalahmasalah organisasi, serta mengabsahkan tes yang digunakan dalam seleksi karyawan. Meskipun demikian, penilaian kinerja masih hanya digunakan untuk mencapai tujuan administratif dan pengembangan karyawan (Harisantoso, 2018).

Dalam institusi pendidikan tinggi, evaluasi kinerja dosen memiliki tiga tujuan di atas. Namun secara lebih khusus, tujuan evaluasi dosen adalah untuk: (1) Meningkatkan kualitas pengajaran, (2) Mengembangkan diri dosen, (3) Meningkatkan kepuasan mahasiswa terhadap pengajaran, (4) Meningkatkan kepuasan kerja dosen, (5) Mencapai tujuan program studi/fakultas/universitas, serta (6) Meningkatkan penilaian masyarakat terhadap fakultas/universitas. Evaluasi dosen merupakan proses analitis yang intrinsik dalam pengajaran yang baik. Dengan kata lain, evaluasi dosen merupakan suatu kesatuan dalam kegiatan belajar-mengajar yang baik (good teaching). Pengajaran yang baik membantu mahasiswa untuk mencapai pembelajaran berkualitas baik (high quality learning). Kualitas pengajaran dan standar akademik perlu untuk selalu dievaluasi dan ditingkatkan karena pendidikan tinggi merupakan kegiatan yang mahal (Chairy, 2005).

Kinerja dosen berdampak pada karir kepangkatannya. Kepangkatan dosen tersebut dimulai dari asisten ahli, lektor, lektor kepala dan guru besar. Untuk melalui dan mandapatkan kepangkatan tersebut, seorang dosen harus berusaha melakukan tugas dan kewajibannya sebagai dosen sesuai dengan Tridharma perguruan tinggi (Kemenristekdikti, 2016).

Pelaksanaan pendidikan dan pengajaran dapat dilaksanakan dengan sistem perkuliahan biasa, sistem asistensi, sistem modul, dan team teaching. Tugas penelitian dan publikasi merupakan kegiatan yang wajib dilakukan oleh dosen, baik secara perorangan maupun berkelompok, dibiayai secara mandiri maupun oleh lembaga. Dosen wajib menjalankan dharma penelitian dan publikasi bersama-sama dengan dharma pendidikan dan pengajaran dengan bobot sekurang-kurangnya sembilan SKS setiap semester. Tugas pengabdian kepada masyarakat wajib dilaksanakan oleh setiap dosen melalui kegiatan pengabdian kepada masyarakat sebanyak-banyaknya setara dengan tiga SKS dalam satu semester. Tugas penunjang tridharma perguruan tinggi dapat diperhitungkan sebanyakbanyaknya sepadan dengan tiga SKS setiap semester (LPM UINAM, 2016).

Dalam Tridharma Perguruan Tinggi, dosen harus melakukan dengan beban kerja paling sedikit sepadan dengan dua belas SKS dan paling banyak enam belas SKS pada setiap semester sesuai dengan kualifikasi akademik. Pelaksanaan tugas utama dosen ini perlu dievaluasi dan dilaporkan secara periodik sebagai bentuk akuntabilitas kinerja dosen kepada para pemangku kepentingan (Tim Penyusun BKD, 2010). Kompetensi dosen menentukan kualitas pelaksanaan Tridharma Perguruan Tinggi sebagaimana yang ditunjukkan dalam kegiatan profesional dosen (Maqin, 2016). Berdasarkan hal ini maka perlu diadakan evaluasi kinerja dosen dalam melaksanakan pendidikan dan pengajaran di STA Jember. 


\section{KAJIAN LITERATUR \\ Evaluasi Kinerja}

Keberhasilan organisasi dalam mencapai tujuan dapat diketahui dengan menggunakan penilaian kegiatan organisasi tersebut berdasarkan peraturan, norma dan etika yang berlaku.

Evaluasi atau pengukuran kinerja dapat dilakukan melalui dua pendekatan. Pertama, membandingkan hasil yang dicapai dengan standar atau tolak ukur hasil atau tujuan yang harus dicapai. Kedua, terutama untuk mengukur kinerja yang hasilnya non fisik, yaitu dengan membandingkan pekerjaan atau tugas yang nyata-nyata dilakukan dengan uraian jabatan atau uraian tugas yang selayaknya dikerjakan dengan benar dan tepat (Simanjuntak, 2011). Menggison mengemukakan evaluasi kinerja adalah suatu proses yang digunakan pimpinan untuk menentukan apakah seorang karyawan melakukan pekerjaannya sesuai dengan tugas dan tanggung jawabnya (Mangkunegara, 2017). Berikut ini definisi evaluasi kinerja sebagaimana dikutip oleh Wirawan (2015):

a. Dick Grote, performance apprasial adalah sistem manajemen formal yang disediakan untuk evaluasi kualitas individu pada sebuah organisasi.

b. Cynthia D. Fisher, Lyle F. Schoefeldt \& James B. Shaw, performance appraisal adalah sebuah proses dari kontribusi pegawai untuk sebuah organisasi selama periode tertentu dinilai.

c. Wayne F. Cascio, performance appraisal adalah deskripsi sistematis kelebihan dan kekurangan pegawai dalam melakukan pekerjaan.

d. R. Wayne Mondy et. al., performance appraisal adalah sistem peninjauan dan penilaian kinerja pekerjaan individu atau tim.

e. Tom Coens dan Mary Jenkins, performance appraisal adalah proses evaluasi atau memutuskan bagaimana seseorang difungsikan.

f. Latham, Gary P. \& wexley, Kenneth N, performance appraisal adalah keputusan manajemen yang memengaruhi ingatan, pemecatan, promosi, demosi, pemindahan, peningkatan atau pemotongan gaji, atau pengikutsertaan individu pada suatu program pelatihan.

g. Society for Human Resource Management, proses evaluasi sejauh mana kinerja pegawai dalam bekerja ketika dibandingkan dengan serangkaian standar dan mengkomunikasikan informasi tersebut pada pegawai.

h. Erdogan, Berrin; performance appraisal mengacu pada keseluruhan prosedur, yang mencakup penetapan standar kinerja, perilaku para penilai ketika melakukan penilaian selama periode penilaian kinerja, penentuan peringkat kerja dan pengomunikasian peringkat tersebut kepada ternilai.

berikut:

Rismawati dan Mattalata (2018) memberikan pengertian evaluasi kinerja sebagai

a. Suatu sistem formal dan terstruktur yang mengukur, menilai, dan memengaruhi sifatsifat yang berkaitan dengan pekerjaan, perilaku dan hasil termasuk tingkat ketidakhadiran. Fokusnya adalah untuk mengetahui seberapa produktif seorang karyawan dan apakah ia bisa berkinerja atau lebih efektif pada masa yang akan datang, sehingga karyawan, perusahaan dan masyarakat semuanya memperoleh manfaat.

b. Pencapaian tujuan yang telah ditetapkan merupakan salah satu tolak ukur keja individu.

c. Evaluasi kinerja adalah proses evaluasi seberapa baik karyawan mengerjakan pekerjaaanya ketika dibandingkan denga satu set standar dan kemudian mengkomunikasikannya dengan karyawan. Evaluasi demikian disebut sebagai penilaian karyawan, evaluasi karyawan, tinjauan kinerja, evaluasi kinerja dan evaluasi hasil. 
d. Evaluasi kinerja pada dasarnya merupakan faktor kunci guna mengembangkan suatu perusahaan secara efektif dan efisien, karena adanya kebijakan atau program yang lebih baik atas sumber daya manusia yang ada dalam perusahaan. Evaluasi kinerja individu sangat bermanfaat bagi dinamika pertumbuhan perusahaan secara keseluruhan, melalui evaluasi tersebut maka dapat diketahui kondisi sebenarnya tentang bagaimana kinerja karyawan.

Dari beberapa pendapat di atas, dapat disimpulkan bahwa evaluasi kinerja adalah penilaian yang dilakukan secara sistematis untuk mengetahui hasil pekerjaan karyawan dan kinerja organisasi.

\section{Kinerja Dosen}

Kinerja dosen pada suatu perguruan tinggi merupakan perilaku nyata yang ditampilkan setiap dosen sebagai prestasi kerja yang dihasilkan oleh dosen tersebut sesuai dengan peranannya. Kinerja dosen merupakan suatu hal yang sangat penting dalam upaya lembaga perguruan tinggi untuk mencapai tujuanya. Di dalam dunia yang kompetitif dan mengglobal, setiap perguruan tinggi, memerlukan kinerja dosen yang tinggi. Pada saat yang bersamaan, dosen sebagai ujung tombak suatu perguruan tinggi memerlukan umpan balik dari lembaga atas hasil kerja mereka sebagai panduan bagi perilaku mereka di masa yang akan datang. Umpan balik terhadap kinerja dosen dapat dilakukan melalui evaluasi kinerja (Universitas Ngudi Waluyo, 2017).

Berdasarkan penjelasan di atas tentang kinerja dapat disimpulkan bahwa yang dimaksud kinerja dosen adalah pencapaian kerja yang dilakukan oleh dosen dalam melaksanakan tugasnya. Lebih tepatnya, kinerja dosen dimaknai sebagai kuantitas dan kualitas pekerjaan yang diselesaikan oleh dosen sesuai dengan tata aturan yang mengikat di perguruan tinggi maupun perundangan-perundangan yang berlaku.

Kinerja Depdiknas 2004 menyatakan kinerja dosen adalah kemampuan untuk melaksanakan pekerjaan atau tugas yang dimiliki dosen dalam menyelesaikan suatu pekerjaannya. Kriteria kinerja pendidikan menurut Blazey, bertujuan untuk: (1) meningkatkan kinerja dan output pendidikan, (2) mempermudah komunikasi dan tukar menukar informasi tentang praktik pendidikan yang terbaik dengan berbagai tipe institusi pendidikan, dan (3) sebagai alat untuk memahami dan meningkatkan kinerja institusi pendidikan (Blazey, 2001).

Dalam melaksanakan tugasnya, dosen harus memiliki empat kompetensi sebagai berikut (Tim Penyusun BKD, 2017):

a. Kompetensi profesional, yakni keluasan wawasan akademik dan kedalaman pengetahuan dosen terhadap materi keilmuan yang ditekuninya.

b. Kompetensi pedagogik, yakni penguasaan dosen pada berbagai macam pendekatan, metode, pengelolaan kelas, dan evaluasi pembelajaran yang sesuai dengan karakteristik materi dan perkembangan mahasiswa

c. Kompetensi kepribadian, yakni kesanggupan dosen untuk secara baik menampilkan dirinya sebagai teladan dan memperlihatkan antusiasme dan kecintaan terhadap profesinya

d. Kompetensi sosial, yakni kemampuan dosen untuk menghargai kemajemukan, aktif dalam berbagai kegiatan sosial, dan mampu bekerja dalam team work.

Pedoman evaluasi kinerja dosen ini disusun dengan mempertimbangan perundangundangan yang berlaku di Indonesia:

a. Undang-Undang Republik Indonesia Nomor 20 Tahun 2003 Tentang Sistem Pendidikan Nasional. 
b. Undang-Undang Republik Indonesia Nomor 14 Tahun 2005 Tentang Guru dan Dosen.

c. Peraturan Pemerintah Republik Indonesia Nomor 37 Tahun 2009 Tentang Dosen.

d. Permenpan Nomor 17 Tahun 2013 Tentang Jabatan Fungsional Dosen dan Angka Kredit.

e. Peraturan Pemerintah Republik Indonesia Nomor 4 Tahun 2014 Tentang Penyelenggaraan Pendidikan Tinggi dan Pengelolaan Perguruan Tinggi.

f. Peraturan Menteri Pendidikan dan Kebudayaan Republik Indonesia Nomor 49 Tahun 2014 Tentang Standar Nasional Pendidikan Tinggi.

g. Peraturan Menteri Pendidikan dan Kebudayaan Republik Indonesia Nomor 50 Tahun 2014 Tentang Sistem Penjaminan Mutu Internal.

h. Peraturan Kemenristik Dikti Nomor 44 Tahun 2015 tentang Standar Nasional Pendidikan Tinggi.

Tujuan evaluasi kinerja dosen adalah untuk (Tim Penyusun BKD, 2010):

a. meningkatkan profesionalisme dosen dalam melaksanakan tugas;

b. meningkatkan proses dan hasil pendidikan;

c. menilai akuntabilitas kinerja dosen di perguruan tinggi;

d. meningkatkan atmosfer akademik di semua jenjang perguruan tinggi;

e. mempercepat terwujudnya tujuan pendidikan nasional.

Adapun manfaat dari evaluasi kinerja dosen adalah (Tim Penyusun Unissula, 2018):

a. Sebagai salah satu sumber informasi dalam perencanaan pelatihan dan pengembangan dosen.

b. Membantu dalam penetapan tugas mengajar atau dalam mengampu suatu mata kuliah.

c. Sebagai alat untuk membantu dan mendorong dosen untuk mengambil inisiatif dalam upaya memperbaiki kinerja.

d. Untuk mengetahui efektivitas kebijakan yang berkaitan dengan SDM, seperti seleksi, rekruetment serta pelatihan dan pengembangan.

e. Sebagai sumber informasi terkait dengan kebijakan untuk mengatasi permasalahan terkait dengan kinerja dosen.

f. Sebagai sumber informasi untuk pengambilan keputusan yang berkaitan dengan gaji, insentif, upah, konpensasi dan berbagai imbalan lainnya serta pemberian sanksi maupun kebijakan pemberhentian dosen.

\section{Tugas dan Tanggung Jawab serta Profesionalisme Dosen STA Jember}

Dalam buku panduan akademik STA Jember pada BAB XX Pasal 52 disebutkan tugas dan tanggung jawab dosen adalah:

1. Tugas pokok seorang dosen adalah melaksanakan Tridharma Perguruan Tinggi berupa pendidikan dan pengajaran, penelitian, dan pengabdian kepada masyarakat, serta tugastugas pendukung lainnya.

2. Tugas pendidikan dan pengajaran adalah memberi kuliah, melaksanakan praktikum, memberikan bimbingan akademis, dan mengevaluasi hasil belajar mahasiswa dengan rincian sebagai berikut:

a. Merencanakan dan mempersiapkan bahan pembelajaran dengan penguasaan materi yang baik sesuai dengan kurikulum dan silabus yang telah ditetapkan.

b. Melaksanakan pengelolaan kelas dengan baik.

c. Memberikan bimbingan akademis.

d. Menerapkan metode pembelajaran yang sesuai dengan bahan ajar dan kondisi mahasiswa peserta kuliah.

e. Updating materi pembelajaran dan referensi yang cukup. 
f. Menyiapkan Satuan Acara Perkuliahan (SAP), penulisan buku ajar (diktat, modul, handout), Silabus, membuat Kontrak Pembelajaran.

g. Memberikan tugas-tugas kepada mahasiswa baik terstruktur, maupun mandiri, serta memeriksa dan menilainya secara obyektif.

h. Melaksanakan kuis, latihan, dan kegiatan-kegiatan pendalaman materi

i. Memberikan ujian, memeriksa jawaban, serta mengembalikan dan membahas jawaban ujian tersebut bersama mahasiswa.

j. Menyampaikan saran-saran perbaikan berdasarkan hasil evaluasi.

3. Melakukan penelitian ilmiah dan menghasilkan penelitian dan karya ilmiah (minimal setiap semester menghasilkan satu karya ilmiah dan di seminarkan di awal semester dengan dihadiri dosen, staf dan mahasiswa).

4. Hasil penelitian dipublikasikan melalui jurnal STA Jember.

5. Membimbing dan membangkitkan motivasi mahasiswa serta menjadi teladan yang baik.

Berikutnya dalam Pasal 53 disebutkan profesionalisme dosen adalah nilai kultural, untuk senantiasa menyuguhkan karya terbaik (best practices) secara terus menerus tanpa batas (infinite searching). Sesuai dengan profesinya, profesionalisme seorang dosen bukan hanya terkait dengan penguasaannya terhadap suatu disiplin ilmu dan keahlian tertentu, tetapi juga dituntut amalan terbaiknya dalam penyelenggaraan pendidikan, penelitian, dan pengabdian/pelayanan pada masyarakat. Dengan demikian seorang dosen yang profesional mempunyai peran ganda, yaitu senantiasa memelihara dan mengembangkan profesionalisme dalam bidang keilmuan dan keahliannya, sekaligus berusaha memahami dan meningkatkan kepuasan pelanggannya. Pelanggan utama dosen adalah mahasiswa.

Profesionalisme dosen merupakan salah satu tolok ukur dalam sistem penjaminan mutu akademik. Profesionalisme harus menjadi nilai kultural yang dimiliki dosen untuk selalu menampilkan karya terbaik dalam melaksanakan tugas dan tanggung jawabnya sebagai dosen. Namun demikian pencapaian profesionalisme dosen bukan hanya menjadi tanggung jawab dosen, tetapi menjadi tanggung jawab bersama antara dosen dan institusinya. Institusi berkewajiban untuk menciptakan sistem yang mengupayakan pengembangan kemampuan profesionalisme dosen.

Institusi juga harus menetapkan kriteria dosen dan manajemen mutu dosen demi tercapainya profesionalisme dosen. Seorang dosen Sekolah Tinggi Alkitab Jember yang profesional sekurang-kurangnya memiliki karakter sebagai berikut:

a. Patuh pada etika akademik dan bertanggung jawab terhadap profesi dan masyarakat;

b. Memiliki komitmen untuk peningkatan mutu;

c. Menciptakan budaya mutu dalam pikiran, perasaan dan tindakan cendikiawan;

d. Memiliki kompetensi yang diakui dalam bidang akademik;

e. Senantiasa melakukan refleksi diri menuju ke peningkatan kompetensi;

f. Mandiri, dan mampu mengatur diri;

g. Peduli, tulus, dan ikhlas dalam melaksanakan tugasnya;

h. Loyal dan berdedikasi tinggi.

Kode etik dosen sebagaimana dijelaskan pada Pasal 54, merupakan salah satu ramburambu yang diperlukan para dosen berkaitan dengan sikap, perilaku dan tindakannya selama menjalankan tugasnya baik di lingkungan kampus STA Jember maupun di lingkungan masyarakat. Kode etik dosen STA Jember mencakup beberapa hal yaitu:

a. Kode etik terkait profesionalisme

b. Jujur secara intelektual dan menunjukkan kebenaran di dalam melaksanakan tugasnya

c. Disiplin terhadap diri sendiri dalam menggunakan, memperluas dan menyebarkan pengetahuan

d. Objektif dan adil di dalam hubungan profesional dan menghargai kolega; 
e. Objektif dan apresiatif terhadap pertanyaan dan kritik yang diajukan oleh kolega terhadap pekerjaannya

f. Jujur mengungkapkan kebenaran yang dapat dipertanggung jawabkan secara alkitabiah, dan akademis

g. Tidak melakukan plagiat

h. Menjaga nama baik Sekolah Tinggi Alkitab Jember

i. Menghargai mahasiswa secara personal dan sebagai mitra intelektual Menyatakan dirinya bukan sebagai seorang yang paling tahu tentang ilmu pengetahuan dalam bidangnya

j. Menyampaikan keterangan yang dapat dibuktikan kebenarannya

k. Menghindari tindakan-tindakan yang bertentangan dengan standar moral, hukum, dan nilai-nilai iman Kristen.

Salah satu peran yang diharapkan dari seorang dosen adalah dapat membangun atmosfer akademik. Atmosfer akademik adalah suasana lingkungan yang memungkinkan terjadinya hubungan yang sehat antara mahasiswa dengan dosen, antar dosen, serta antar

mahasiswa. Suasana kondusif diperlukan untuk memungkinkan pengembangan potensi semua pihak secara maksimal, terutama mahasiswa dan dosen, dalam mencapai standar mutu akademik yang unggul. Suasana ini harus tercipta dalam seluruh bidang kegiatan akademik,

yaitu: pendidikan, penelitian, dan pengabdian/pelayanan pada masyarakat, di segenap tempat dan lapisan baik di kampus maupun di luar kampus Sekolah Tinggi Alkitab Jember. Beban tugas dosen STA Jember dalam melaksanakan Tridharma Perguruan Tinggi yaitu:

a. Beban Tugas atau Ekivalensi Waktu Mengajar Penuh (EWMP) seorang dosen adalah 12 SKS per-semester, dengan pengertian 1 SKS setara dengan tiga jam kerja per minggu selama satu semester.

b. Beban tugas dosen dapat terdiri atas tugas memberikan kuliah/ praktikum, penelitian dan menghasilkan karya ilmiah, melakukan kegiatan pengabdian kepada masyarakat, serta kegiatan penunjang akademis.

c. Tugas penelitian dapat dilakukan secara perorangan atau kelompok, sekurang-kurangnya satu penelitian dalam masa satu tahun akademik.

d. Tugas pengabdian kepada masyarakat dapat dilakukan secara perorangan atau kelompok, sekurang-kurangnya dua kegiatan pengabdian kepada masyarakat dalam masa satu tahun akademik.

e. Beban tugas dosen luar biasa antara $4-6 \mathrm{SKS}$.

\section{Metode 360 Derajat}

Ada beberapa model evaluasi kinerja yang telah dikembangkan oleh para ahli. Pada penelitian ini model yang digunakan adalah model evaluasi kinerja 360 derajat dimana penilai lebih dari satu. Penilaian kinerja dosen berdasarkan penilaian dari ketua, rekan sejawat, mahasiswa dan bagaimana penilaian dosen itu sendiri terhadap dirinya sendiri. Alasan mendasar dari pemilihan model ini adalah dengan harapan objektivitas penilaian lebih tinggi dibandingkan dengan hanya penilaian oleh atasan langsung yang umumnya digunakan pada saat ini. Karena dalam penilaian prestasi/kinerja, yang perlu diperhatikan adalah bagaimana menerapkannya secara objektif dan fair. Objektif dalam arti bahwa nilai yang diberikan benar-benar sesuai dengan tingkat pencapaian yang diukur, dan fair dalam arti bahwa penilaiannya didasarkan pada standar yang telah disepakati (Michael A, 2012).

Para penilai adalah orang yang berada di sekitar tempat kerja yang dapat mengobservasi secara langsung apa yang dilakukan pegawai dalam melaksanakan pekerjaannya. Setiap penilai berinteraksi secara tetap dengan ternilai dan mengobservasi domain kinerja ternilai ketika melaksanakan pekerjaannya dan mengumpulkan informasi 
yang diperlukan. Hasil penilai dianalisis untuk mendapatkan nilai rata-rata yang kemudian diberikan kepada ternilai sebagai balikan. Pegawai ternilai menerima balikan hasil evaluasi kinerja tersebut secara anonimus dan konfidensial. Penggunaan lebih dari satu penilai ini menguntungkan. Cara ini membantu mengatasi masalah seperti biasa dalam penilaian individual (Gary Dessler, 2005).

Model evaluasi kinerja 360 derajat dirancang dan dilaksanakan untuk manfaat dan keuntungan pegawai dan perusahaan/organisasi, sebagai berikut (Gary Dessler, 2005):

a. Dengan mempergunakan multipenilai model evaluasi kinerja ini menghasilkan informasi lebih seimbang dan komprehensif. Informasi lebih dapat dipercaya, valid sebab penilai berinteraksi secara tetap dengan pegawai ternilai yang sedang melaksanakan pekerjaannya.

b. Menghilangkan kesalahan yang terjadi dalam evaluasi kinerja: halo error, leniency error, strickty error, central tendency error, similar to me error dan subjektivitas dalam evaluasi kinerja.

c. Menyediakan kepada pegawai peluang untuk memahami bagaimana persepsi para penilai mengenai kinerjanya yang dapat saja berbeda satu sama lain.

d. Meningkatkan pemahaman perilaku, sifat pribadi, kompetensi yang diperlukan untuk menciptakan kinerja dan meningkatkan efektivitas dan efisiensi individu pegawai dan perusahaan/organisasi.

e. Mendorong pengembangan diri dan profesionalisme pegawai dengan menyediakan masukan kunci untuk prioritas dan perencanaan pengembangunan.

f. Mengembangkan budaya komunikasi terbuka antara para pemangku kepentingan yang terkait dengan evaluasi kinerja. Mereka percaya bahwa para penilai merupakan orangorang profesional yang mempunyai integritas dalam melaksanakan penilaian.

g. Mengembangkan komunikasi dua arah antara para pegawai dengan organisasi.

h. Memicu perubahan individual pegawai dan organisasi.

i. Menjaga kerahasiaan penilaian dan balikan hanya disampaikan kepada pegawai ternilai secara konfidensial.

Keunggulan model evaluasi kinerja 360 derajat antara lain (Gary Dessler, 2005):

a. Model evaluasi ini dapat membantu organisasi meluruskan kompetensi pegawai dengan visi dan misi organisasi. Evaluasi kinerja dapat memfokuskan sikap pada hasil yang dapat membuat perusahaan dapat mencapai tujuannya.

b. Para peneliti umumnya menyimpulkan bahwa model evaluasi kinerja dengan mempergunakan multipenilai memberikan informasi yang lebih komprehensif dan lebih akurat mengenai kinerja ternilai daripada kalau dilakukan oleh penilai tunggal. Informasi tersebut lebih adil dan termotivasi.

c. Mengembangkan budaya dan norma mengenai evaluasi kinerja memberikan hubungan kerja yang lebih profesional dan lancar dengan mempergunakan tim kerja. Jika diterapkan secara sistematis akan menciptakan iklim organisasi kepercayaan, keterbukaan yang akan meningkatkan kinerja pegawai dan organisasi.

d. Memperbaiki komunikasi interpersonal mengenai hubungan kerja dan mengembangkan perilaku kerja para pegawai dan mengembangkan organisasi pembelajaran.

e. Meningkatkan objektivitas dengan menghilangkan subjectivitas dalam evaluasi kinerja dan quality work of life.

Di samping keunggulan, model evaluasi kinerja 360 derajat mempunyai sejumlah kelemahan (Gary Dessler, 2005):

a. Mahal. Model evaluasi kinerja ini lebih mahal karena memerlukan beberapa penilai yang harus mengobservasi ternilai dalam waktu tertentu. 
b. Penilai tak punya cukup waktu untuk menilai sepanjang tahun. Jika 5 penilai harus menilai 20 pegawai ternilai dan harus mengobservasinya sepanjang tahun merupakan pekerjaan penuh waktu sepanjang tahun. Seorang supervisor yang harus mengevaluasi kinerjanya umumnya kurang mempunyai waktu cukup untuk mengembangkan pekerjaan manajerialnya. Seorang bawahan yang harus menilai manajer atasannya hanya dapat mengobservasi apa yang dilakukan atasannya misalnya dalam memberi perintah atau mengambil keputusan bukan semua aspek pekerjaan manajerialnya.

c. Kolusi. Seorang pegawai yang harus saling menilai kinerja teman sekerjanya mungkin dapat melakukan kolusi.

Adapun tahapan pelaksanaan penilaian kinerja dengan sistem penilaian 360 derajat adalah sebagai berikut (Lepsinger, Aanntoinette \& Lucia, 1997):

1. Mengembangkan kuesioner: kuesioner yang digunakan untuk sistem penilaian kinerja 360 derajat memuat pertanyaanpertanyaan dengan menggunakan sistem skala 1-5.

2. Memastikan kepercayaan para partisipan: langkah-langkah harus diambil untuk memastikan kepercayaan terhadap hasil umpan balik yang didapatkan

3. Menyediakan pelatihan atau orientasi: seringkali proses umpan balik melibatkan satu atau lebih kuesioner, informasi yang rahasia dan keterlibatan dari berbagai divisi di dalam organisasi.

4. Pengawasan umpan balik dari kuesioner: distribusikan kuesioner dengan mencantumkan instruksi sehingga mencegah kesalahpahaman

5. Analisis data: analisis data akan meliputi penilaian rata-rata.

Dalam penggunaan model 360 derajat, identitas penilai sebaiknya dirahasiakan agar hasil penilaian lebih akurat dimana penilai tidak akan merasa terbebani apabila hasil penilaian akan memengaruhi hubungan penilai dan ternilai sebagai efek hasil penilaian.

\section{Kriteria Evaluasi Kinerja}

Untuk penyusunan kriteria evaluasi umumnya didasarkan pada: Pertama adalah peraturan atau ketentuan yang sudah dikeluarkan berkenaan dengan kebijakan tersebut, kalau tidak ada maka akan digunakan ketentuan yang berlaku umum. Sumber kedua adalah Pedoman Pelaksanaan. Sumber ketiga adalah teori-teori yang terdapat dalam buku-buku ilmiah. Sumber keempat adalah hasil penelitian yang sudah dipublikasikan atau diseminarkan. Sumber kelima adalah minta pertimbangan kepada orang yang dipandang mempunyai kelebihan dalam bidang yang sedang dievaluasi (expert judgment). Sumber keenam adalah menyusun kriteria bersama-sama dengan anggota tim (kesepakatan kelompok) dan yang ketujuh adalah melakukan pemikiran sendiri dengan menggunakan akal dan nalar (Suharsimi dan Cepi Safruddin'2009).

Dalam penelitian ini, kriteria yang peneliti gunakan sebagai patokan atau tolak ukur adalah kriteria kuantitatif. Suharsimi dan Cepi Safruddin (2009) menyatakan bahwa kriteria kuantitatif dapat dibedakan menjadi dua yaitu kriteria tanpa pertimbangan dan kriteria dengan pertimbangan. Peneliti menggunakan kriteria kuantitatif tanpa pertimbangan, artinya kriteria yang disusun hanya dengan memperhatikan rentangan bilangan tanpa mempertimbangkan apa-apa dilakukan dengan membagi rentangan bilangan. Sebagai contoh, kondisi maksimal yang diharapkan diperhitungkan 100\%. Jika penyusun menggunakan lima kategori nilai maka antara 1\% dengan 100\% dibagi rata sehingga menghasilkan kategori (Suharsimi dan Cepi Safruddin' 2009). Untuk lebih jelasnya kriteria evaluasi kinerja dosen seperti nampak pada tabel berikut ini: 
Tabel 1. Kriteria Evaluasi Kinerja

\begin{tabular}{|c|c|c|}
\hline $\begin{array}{l}\text { Komponen } \\
\text { Evaluasi }\end{array}$ & Aspek yang Dievaluasi & Kriteria Evaluasi \\
\hline \multirow{15}{*}{$\begin{array}{l}\text { Pendidikan } \\
\text { dan } \\
\text { Pengajaran }\end{array}$} & $\begin{array}{l}\text { a. Kinerja dalam merencanakan } \\
\text { pembelajaran }\end{array}$ & \multirow{15}{*}{$\begin{aligned} \text { a. } & \text { Sangat Baik (SB), } \\
& \text { jika mencapai } \\
& 81-100 \% . \\
\text { b. } & \text { Baik (B), jika } \\
& \text { mencapai } \\
& 61-80 \% . \\
\text { c. } & \text { Cukup (C), jika } \\
& \text { mencapai } \\
& 41-60 \% . \\
\text { d. } & \text { Kurang Baik (KB), } \\
& \text { jika mencapai } \\
& 21-40 \% . \\
\text { e. } & \text { Sangat Kurang Baik } \\
& \text { (SKB), jika } \\
& \text { mencapai } \\
& 1-20 \% .\end{aligned}$} \\
\hline & $\begin{array}{l}\text { b. Kinerja dalam melaksanakan } \\
\text { pembelajaran }\end{array}$ & \\
\hline & $\begin{array}{l}\text { c. Kinerja dalam mengembangkan sumber } \\
\text { belajar }\end{array}$ & \\
\hline & d. Kinerja dalam mengevaluasi pembelajaran & \\
\hline & $\begin{array}{l}\text { e. Kinerja dalam mengaplikasikan berbagai } \\
\text { metode pembelajaran }\end{array}$ & \\
\hline & f. Penguasaan materi pembelajaran & \\
\hline & $\begin{array}{l}\text { g. Kinerja memanfaatkan IPTEK dalam } \\
\text { perkuliahan }\end{array}$ & \\
\hline & h. Inovasi dan kreativitas dalam perkuliahan & \\
\hline & i. Mengajar sesuai dengan beban kerja dosen & \\
\hline & j. Kedisiplinan dalam mengajar & \\
\hline & k. Kewibawaan sebagai dosen & \\
\hline & 1. Kearifan dalam mengambil keputusan & \\
\hline & m. Menjadi teladan dalam sikap dan perilaku & \\
\hline & $\begin{array}{l}\text { n. Kemampuan mengendalikan diri dalam } \\
\text { berbagai situasi dan kondisi }\end{array}$ & \\
\hline & o. Adil dalam memperlakukan mahasiswa & \\
\hline
\end{tabular}

\section{METODE PENELITIAN}

Untuk mengetahui kinerja dosen dalam melaksanakan pendidikan dan pengajaran di STA Jember maka penelitian ini menggunakan evaluative research, secara khusus evaluasi kinerja. Dalam penelitian evaluasi kinerja ini, model yang digunakan adalah evaluasi kinerja 360 derajat (360 Degree Performance Appraisal Model). Secara umum model evaluasi ini bertujuan untuk mengukur apakah kinerja dosen sesuai dengan standar atau kriteria kinerja yang sudah ditentukan. Penilaian kinerja dosen tersebut dilakukan oleh multi penilai atau penilaian dilakukan oleh beberapa orang. Para penilai merupakan orang-orang yang berada di sekitar lingkungan kerja yang mampu mengobservasi secara langsung apa yang dilakukan dosen dalam melaksanakan pekerjaannya. Pada penelitian ini penilainya terdiri dari: dosen yang bersangkutan; Ketua yaitu atasan langsung yang mengawasi pekerjaan/kinerja dosen yang bersangkutan atau penilai yang ditunjuk oleh Ketua; mahasiswa; teman sejawat, yaitu rekan sekerja dari dosen yang akan dinilai yang mengetahui secara langsung dosen yang bersangkutan.

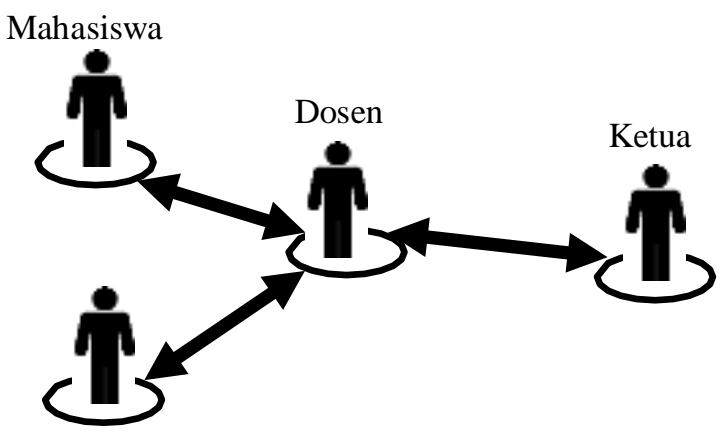

Rekan Dosen

Gambar 1. Model Evaluasi Kinerja 360 Derajat Dosen Sekolah Tinggi Alkitab Jember 
Dalam upaya untuk mengetahui kinerja dosen dalam melaksanakan pendidikan dan pengajaran di STA Jember menggunakan metode kualitatif karena penelitian ini dimaksudkan untuk meneliti objek lebih mendalam serta rinci dari jumlah responden yang sedikit.

Pendekatan kualitatif dilakukan untuk mengolah data yang bersumber dari observasi, wawancara, studi dokumentasi dan kuesioner. Data yang didapat dianalisis dan dicari hubungannya, dibandingkan, kemudian menemukan pola dasar dari data aslinya. Pemaparan hasil analisis mengenai situasi yang diteliti disajikan dalam format uraian naratif. Hasil penilaian akan diolah berdasarkan ketentuan penilaian komponen kriteria, dengan rekapitulasi akhir diperoleh rumus:

$$
\mathrm{NA}=(\text { Jumlah skor/Skor maksimal }) \times 100 \%
$$

Skor ketercapaian dan rekapitulasi akhir disajikan dalam bentuk persen dengan kategori sebagai berikut:

Tabel 2. Skor Ketercapaian

\begin{tabular}{|c|c|}
\hline Skor (\%) & Penafsiran \\
\hline $81-100$ & Sangat Baik (SB) \\
\hline $61-80$ & Baik (B) \\
\hline $41-60$ & Cukup (C) \\
\hline $21-40$ & Kurang Baik (KB) \\
\hline $1-20$ & Sangat Kurang Baik (SKB) \\
\hline
\end{tabular}

Partisipan dalam penelitian ini berjumlah tujuh belas orang yang merupakan dosen tetap pada STA Jember Tahun Akademik 2018/2019. Alamat STA Jember berada di Jl. Letjen Suprapto VI No. 86 Kebonsari Jember Jawa Timur. 


\section{HASIL DAN PEMBAHASAN}

Berdasarkan hasil wawancara dari enam orang dosen yang dipilih mewakili keseluruhan responden yaitu Ketua, Kaprodi Teologi, Kaprodi PAK dan tiga dosen, menunjukkan kinerja dosen STA Jember dalam melaksanakan pendidikan dan pengajaran sebagai berikut:

Semua dosen membuat silabus tetapi hanya beberapa yang melengkapi dengan SAP dan Kontrak perkuliahan. Dalam mengajar, dosen menggunakan diktat atau buku ajar, ada juga yang hanya menggunakan powerpoint dari materi yang sudah disiapkan. Dosen mengajar sesuai BKD (Beban Kerja Dosen), disiplin dan sesuai ketentuan akademik. Setiap dosen mengadakan evaluasi pembelajaran dengan memberikan tugas-tugas kepada mahasiswa, UTS (Ujian Tengah Semester), UAS (Ujian Akhir Semester). Jika nilai akhir tidak lulus, maka diadakan remidi atau mahasiswa mengulang pada semester/jadwal berikutnya.

Dalam hal karakter/kepribadian menunjukkan semua dosen baik yaitu disiplin, teliti, teratur, pandai, dapat berdiskusi dan transfer ilmu dengan baik. Memiliki empati dan ketegasan sehingga mahasiswa sangat nyaman untuk sharing, baik masalah pribadi maupun menyangkut kegiatan pembelajaran. Integritas sebagai dosen terlebih sebagai hamba Tuhan dapat terbaca melalui kejujuran. Dalam hal konsistensi, selalu berusaha menepatinya, seperti ketika berjanji kepada mahasiswa untuk memberikan waktu jika mereka hendak konsultasi menyangkut tugas-tugas, termasuk membimbing mereka dalam menyusun proposal, skripsi, tesis. Berkaitan dengan keteladanan, ketika mengajar, selalu berusaha tidak terlambat sebagaimana menasihati mahasiswa untuk tidak terlambat. Dosen adil dalam memperlakukan mahasiswa yang terdiri dari berbagai latar belakang budaya, daerah dan suku.

Berdasarkan observasi, kinerja dosen STA Jember dalam melaksanakan kegiatan pembelajaran yaitu sebagai berikut: Pendahuluan, dosen menunjuk salah satu mahasiswa memimpin doa pembukaan, kemudian dosen dan mahasiswa mendiskusikan kontrak perkuliahan, selanjutnya dosen review materi pada pertemuan sebelumnya. Penyajian, dosen menjelaskan pokok bahasan sesuai SAP (ceramah, tanya jawab dan diskusi), beberapa dosen menyediakan diktat atau buku ajar sedangkan yang lain hanya menampilkan materi lewat power point yang dibagikan ke mahasiswa, dosen mengaitkan materi dengan pengetahuan lain yang relevan dan juga dengan realitas kehidupan, melaksanakan pembelajaran kontekstual, dosen menggunakan LCD dan whiteboard, proses pembelajaran berorientasi pada mahasiswa. Penutup, dosen bertanya tentang materi yang sudah dipelajari (tes lisan), dosen membuat rangkuman materi dengan melibatkan mahasiswa, dosen memberikan tugas baca materi pertemuan berikutnya, doa penutup.

Dalam penelitian ini didukung juga oleh studi dokumentasi berupa dokumen tertulis seperti Silabus, SAP, Kontrak Perkuliahan dan beberapa foto kegiatan dosen dalam mengajar.

Sedangkan berdasarkan data yang diperoleh dari hasil kuesioner maka dapat diketahui bahwa untuk kinerja dalam melaksanakan pendidikan dan pengajaran adalah sebagai berikut: 
Tabel 3. Total Skor Kinerja A dalam Pendidikan dan Pengajaran

\begin{tabular}{|c|c|c|c|c|c|c|c|}
\hline \multirow{2}{*}{ No } & \multirow{2}{*}{ Melaksanakan Pendidikan dan Pengajaran } & \multicolumn{5}{|c|}{ Skor } & \multirow{2}{*}{$\begin{array}{l}\text { Total } \\
\text { Skor }\end{array}$} \\
\hline & & 5 & 4 & 3 & 2 & 1 & \\
\hline $\mathrm{a}$ & Kinerja dalam merencanakan pembelajaran & 20 & 8 & 12 & 0 & 0 & 40 \\
\hline $\mathrm{b}$ & Kinerja dalam melaksanakan pembelajaran & 45 & 4 & 0 & 0 & 0 & 49 \\
\hline $\mathrm{c}$ & Kinerja dalam mengembangkan sumber belajar & 5 & 20 & 9 & 2 & 0 & 36 \\
\hline $\mathrm{d}$ & Kinerja dalam mengevaluasi pembelajaran & 10 & 20 & 9 & 0 & 0 & 39 \\
\hline e & $\begin{array}{l}\text { Kinerja dalam mengaplikasikan berbagai metode } \\
\text { pembelajaran }\end{array}$ & 15 & 20 & 6 & 0 & 0 & 41 \\
\hline $\mathrm{f}$ & Penguasaan materi pembelajaran & 30 & 16 & 0 & 0 & 0 & 46 \\
\hline $\mathrm{g}$ & Kinerja memanfaatkan IPTEK dalam perkuliahan & 0 & 16 & 9 & 6 & 0 & 31 \\
\hline $\mathrm{h}$ & Inovasi dan kreativitas dalam perkuliahan & 5 & 8 & 15 & 4 & 0 & 32 \\
\hline $\mathrm{i}$ & Mengajar sesuai dengan beban kerja dosen & 10 & 24 & 3 & 2 & 0 & 39 \\
\hline $\mathrm{j}$ & Kedisiplinan dalam mengajar & 25 & 16 & 0 & 2 & 0 & 43 \\
\hline $\mathrm{k}$ & Kewibawaan sebagai dosen & 35 & 12 & 0 & 0 & 0 & 47 \\
\hline 1 & Kearifan dalam mengambil keputusan & 20 & 24 & 0 & 0 & 0 & 44 \\
\hline $\mathrm{m}$ & Menjadi teladan dalam sikap dan perilaku & 20 & 24 & 0 & 0 & 0 & 44 \\
\hline $\mathrm{n}$ & $\begin{array}{l}\text { Kemampuan mengendalikan diri dalam berbagai } \\
\text { situasi dan kondisi }\end{array}$ & 10 & 32 & 0 & 0 & 0 & 42 \\
\hline $\mathrm{O}$ & Adil dalam memperlakukan mahasiswa & 20 & 24 & 0 & 0 & 0 & 44 \\
\hline
\end{tabular}

Berdasarkan Tabel 3 dapat diketahui bahwa jumlah skor kinerja dosen A dalam pendidikan dan pengajaran adalah 617. Berdasarkan rumus, maka skor ketercapaian:

$$
\begin{aligned}
& =(617 / 750) \times 100 \% \\
& =82,27 \%
\end{aligned}
$$

Sesuai dengan kriteria evaluasi yang telah ditetapkan berarti sangat baik. Nilai tertinggi berada pada aspek kinerja dalam melaksanakan pembelajaran yaitu 49. Hal ini dimungkinkan karena sudah lebih dari sepuluh tahun mengajar, sedangkan nilai terendah berada pada aspek kinerja memanfaatkan IPTEK dalam perkuliahan yaitu 31 . Hal ini dimungkinkan karena kurangnya penguasaan teknologi.

\begin{tabular}{|c|c|c|c|c|c|c|c|}
\hline \multirow{2}{*}{ No } & \multirow{2}{*}{ Melaksanakan Pendidikan dan Pengajaran } & \multicolumn{5}{|c|}{ Skor } & \multirow{2}{*}{$\begin{array}{l}\text { Total } \\
\text { Skor }\end{array}$} \\
\hline & & 5 & 4 & 3 & 2 & 1 & \\
\hline $\mathrm{a}$ & Kinerja dalam merencanakan pembelajaran & 5 & 28 & 6 & 0 & 0 & 39 \\
\hline $\mathrm{b}$ & Kinerja dalam melaksanakan pembelajaran & 5 & 36 & 0 & 0 & 0 & 41 \\
\hline $\mathrm{c}$ & Kinerja dalam mengembangkan sumber belajar & 5 & 28 & 6 & 0 & 0 & 39 \\
\hline $\mathrm{d}$ & Kinerja dalam mengevaluasi pembelajaran & 5 & 16 & 15 & 0 & 0 & 36 \\
\hline $\mathrm{e}$ & $\begin{array}{l}\text { Kinerja dalam mengaplikasikan berbagai metode } \\
\text { pembelajaran }\end{array}$ & 10 & 16 & 6 & 4 & 0 & 36 \\
\hline $\mathrm{f}$ & Penguasaan materi pembelajaran & 0 & 32 & 6 & 0 & 0 & 38 \\
\hline $\mathrm{g}$ & Kinerja memanfaatkan IPTEK dalam perkuliahan & 15 & 8 & 12 & 2 & 0 & 37 \\
\hline $\mathrm{h}$ & Inovasi dan kreativitas dalam perkuliahan & 5 & 12 & 15 & 2 & 0 & 34 \\
\hline $\mathrm{i}$ & Mengajar sesuai dengan beban kerja dosen & 10 & 16 & 9 & 2 & 0 & 37 \\
\hline $\mathrm{j}$ & Kedisiplinan dalam mengajar & 5 & 24 & 9 & 0 & 0 & 38 \\
\hline $\mathrm{k}$ & Kewibawaan sebagai dosen & 10 & 32 & 0 & 0 & 0 & 42 \\
\hline 1 & Kearifan dalam mengambil keputusan & 5 & 28 & 6 & 0 & 0 & 39 \\
\hline $\mathrm{m}$ & Menjadi teladan dalam sikap dan perilaku & 0 & 40 & 0 & 0 & 0 & 40 \\
\hline $\mathrm{n}$ & $\begin{array}{l}\text { Kemampuan mengendalikan diri dalam berbagai } \\
\text { situasi dan kondisi }\end{array}$ & 0 & 40 & 0 & 0 & 0 & 40 \\
\hline o & Adil dalam memperlakukan mahasiswa & 15 & 28 & 0 & 0 & 0 & 43 \\
\hline & JUMLAH & & & & & & 579 \\
\hline
\end{tabular}

Tabel 4. Total Skor Kinerja B dalam Pendidikan dan Pengajaran 
Berdasarkan Tabel 4 dapat diketahui bahwa jumlah skor kinerja dosen B dalam pendidikan dan pengajaran adalah 579. Berdasarkan rumus, maka skor ketercapaian:

$$
\begin{aligned}
& =(579 / 750) \times 100 \% \\
& =77,2 \%
\end{aligned}
$$

Sesuai dengan kriteria evaluasi yang telah ditetapkan berarti baik. Nilai tertinggi berada pada aspek adil dalam memperlakukan mahasiswa yaitu 41. Hal ini dimungkinkan karena memiliki kompetensi kepribadian yang baik sedangkan nilai terendah berada pada aspek inovasi dan kreativitas dalam perkuliahan yaitu 34. Hal ini dimungkinkan karena kurang mengikuti seminar atau diklat untuk peningkatan kompetensi keilmuan dan keahlian.

\begin{tabular}{|c|c|c|c|c|c|c|c|}
\hline \multirow{2}{*}{ No } & \multirow{2}{*}{ Melaksanakan Pendidikan dan Pengajaran } & \multicolumn{5}{|c|}{ Skor } & \multirow{2}{*}{$\begin{array}{l}\text { Total } \\
\text { Skor }\end{array}$} \\
\hline & & 5 & 4 & 3 & 2 & 1 & \\
\hline $\mathrm{a}$ & Kinerja dalam merencanakan pembelajaran & 0 & 32 & 6 & 0 & 0 & 38 \\
\hline $\mathrm{b}$ & Kinerja dalam melaksanakan pembelajaran & 10 & 24 & 6 & 0 & 0 & 40 \\
\hline $\mathrm{c}$ & Kinerja dalam mengembangkan sumber belajar & 0 & 16 & 15 & 2 & 0 & 33 \\
\hline d & Kinerja dalam mengevaluasi pembelajaran & 10 & 16 & 9 & 2 & 0 & 37 \\
\hline $\mathrm{e}$ & $\begin{array}{l}\text { Kinerja dalam mengaplikasikan berbagai metode } \\
\text { pembelajaran }\end{array}$ & 5 & 28 & 6 & 0 & 0 & 39 \\
\hline $\mathrm{f}$ & Penguasaan materi pembelajaran & 15 & 24 & 3 & 0 & 0 & 42 \\
\hline g & Kinerja memanfaatkan IPTEK dalam perkuliahan & 5 & 16 & 12 & 2 & 0 & 35 \\
\hline $\mathrm{h}$ & Inovasi dan kreativitas dalam perkuliahan & 5 & 12 & 15 & 2 & 0 & 34 \\
\hline i & Mengajar sesuai dengan beban kerja dosen & 5 & 28 & 6 & 0 & 0 & 39 \\
\hline $\mathrm{j}$ & Kedisiplinan dalam mengajar & 5 & 28 & 3 & 2 & 0 & 38 \\
\hline $\mathrm{k}$ & Kewibawaan sebagai dosen & 20 & 24 & 0 & 0 & 0 & 44 \\
\hline 1 & Kearifan dalam mengambil keputusan & 10 & 32 & 0 & 0 & 0 & 42 \\
\hline $\mathrm{m}$ & Menjadi teladan dalam sikap dan perilaku & 0 & 40 & 0 & 0 & 0 & 40 \\
\hline $\mathrm{n}$ & $\begin{array}{l}\text { Kemampuan mengendalikan diri dalam berbagai } \\
\text { situasi dan kondisi }\end{array}$ & 10 & 32 & 0 & 0 & 0 & 42 \\
\hline o & Adil dalam memperlakukan mahasiswa & 10 & 32 & 0 & 0 & 0 & 42 \\
\hline & JUMLAH & & & & & & 585 \\
\hline
\end{tabular}

Tabel 5. Total Skor Kinerja C dalam Pendidikan dan Pengajaran

Berdasarkan Tabel 5 dapat diketahui bahwa jumlah skor kinerja dosen $\mathrm{C}$ dalam pendidikan dan pengajaran adalah 585. Berdasarkan rumus, maka skor ketercapaian:

$$
\begin{aligned}
& =(585 / 750) \times 100 \% \\
& =78 \%
\end{aligned}
$$

Sesuai dengan kriteria evaluasi yang telah ditetapkan berarti baik. Nilai tertinggi berada pada aspek kinerja kewibawaan sebagai dosen yaitu 44. Hal ini dimungkinkan karena memiliki kompetensi kepribadian yang baik sedangkan nilai terendah berada pada aspek kinerja mengembangkan sumber belajar yaitu 33. Hal ini dimungkinkan karena hanya berpusat pada satu sumber belajar. 
Tabel 6. Total Skor Kinerja D dalam Pendidikan dan Pengajaran

\begin{tabular}{|c|c|c|c|c|c|c|c|}
\hline \multirow{2}{*}{ No } & \multirow{2}{*}{ Melaksanakan Pendidikan dan Pengajaran } & \multicolumn{5}{|c|}{ Skor } & \multirow{2}{*}{$\begin{array}{l}\text { Total } \\
\text { Skor }\end{array}$} \\
\hline & & 5 & 4 & 3 & 2 & 1 & \\
\hline $\mathrm{a}$ & Kinerja dalam merencanakan pembelajaran & 10 & 24 & 6 & 0 & 0 & 40 \\
\hline $\mathrm{b}$ & Kinerja dalam melaksanakan pembelajaran & 10 & 24 & 6 & 0 & 0 & 40 \\
\hline $\mathrm{c}$ & Kinerja dalam mengembangkan sumber belajar & 15 & 24 & 3 & 0 & 0 & 42 \\
\hline $\mathrm{d}$ & Kinerja dalam mengevaluasi pembelajaran & 5 & 16 & 12 & 2 & 0 & 35 \\
\hline $\mathrm{e}$ & $\begin{array}{l}\text { Kinerja dalam mengaplikasikan berbagai metode } \\
\text { pembelajaran }\end{array}$ & 15 & 16 & 3 & 4 & 0 & 38 \\
\hline $\mathrm{f}$ & Penguasaan materi pembelajaran & 10 & 28 & 3 & 0 & 0 & 41 \\
\hline $\mathrm{g}$ & Kinerja memanfaatkan IPTEK dalam perkuliahan & 10 & 8 & 18 & 0 & 0 & 36 \\
\hline $\mathrm{h}$ & Inovasi dan kreativitas dalam perkuliahan & 5 & 12 & 12 & 4 & 0 & 33 \\
\hline $\mathrm{i}$ & Mengajar sesuai dengan beban kerja dosen & 10 & 28 & 3 & 0 & 0 & 41 \\
\hline $\mathrm{j}$ & Kedisiplinan dalam mengajar & 15 & 16 & 9 & 0 & 0 & 40 \\
\hline $\mathrm{k}$ & Kewibawaan sebagai dosen & 25 & 16 & 3 & 0 & 0 & 44 \\
\hline 1 & Kearifan dalam mengambil keputusan & 15 & 28 & 0 & 0 & 0 & 43 \\
\hline $\mathrm{m}$ & Menjadi teladan dalam sikap dan perilaku & 20 & 24 & 0 & 0 & 0 & 44 \\
\hline $\mathrm{n}$ & $\begin{array}{l}\text { Kemampuan mengendalikan diri dalam berbagai } \\
\text { situasi dan kondisi }\end{array}$ & 25 & 20 & 0 & 0 & 0 & 45 \\
\hline $\mathrm{o}$ & Adil dalam memperlakukan mahasiswa & 15 & 28 & 0 & 0 & 0 & 43 \\
\hline
\end{tabular}

Berdasarkan Tabel 6 dapat diketahui bahwa jumlah skor kinerja dosen D dalam pendidikan dan pengajaran adalah 605 . Berdasarkan rumus, maka skor ketercapaian:

$$
\begin{aligned}
& =(605 / 750) \times 100 \% \\
& =80,67 \%
\end{aligned}
$$

Sesuai dengan kriteria evaluasi yang telah ditetapkan berarti baik. Nilai tertinggi berada pada aspek kinerja kemampuan mengendalikan diri dalam berbagai situasi dan kondisi yaitu 45 . Hal ini dimungkinkan karena memiliki kompetensi kepribadian yang baik sedangkan nilai terendah berada pada aspek kinerja inovasi dan kreativitas dalam perkuliahan yaitu 33. Hal ini dimungkinkan karena kurang mengikuti seminar atau diklat untuk peningkatan kompetensi keilmuan dan keahlian. 
Tabel 7. Total Skor Kinerja E dalam Pendidikan dan Pengajaran

\begin{tabular}{|c|c|c|c|c|c|c|c|}
\hline \multirow{2}{*}{ No } & \multirow{2}{*}{ Melaksanakan Pendidikan dan Pengajaran } & \multicolumn{5}{|c|}{ Skor } & \multirow{2}{*}{$\begin{array}{l}\text { Total } \\
\text { Skor }\end{array}$} \\
\hline & & 5 & 4 & 3 & 2 & 1 & \\
\hline $\mathrm{a}$ & Kinerja dalam merencanakan pembelajaran & 15 & 16 & 9 & 0 & 0 & 40 \\
\hline $\mathrm{b}$ & Kinerja dalam melaksanakan pembelajaran & 5 & 32 & 3 & 0 & 0 & 40 \\
\hline $\mathrm{c}$ & Kinerja dalam mengembangkan sumber belajar & 5 & 16 & 9 & 2 & 1 & 33 \\
\hline d & Kinerja dalam mengevaluasi pembelajaran & 0 & 16 & 12 & 2 & 1 & 31 \\
\hline $\mathrm{e}$ & $\begin{array}{l}\text { Kinerja dalam mengaplikasikan berbagai metode } \\
\text { pembelajaran }\end{array}$ & 10 & 16 & 3 & 6 & 0 & 35 \\
\hline $\mathrm{f}$ & Penguasaan materi pembelajaran & 10 & 20 & 9 & 0 & 0 & 39 \\
\hline $\mathrm{g}$ & Kinerja memanfaatkan IPTEK dalam perkuliahan & 0 & 12 & 12 & 6 & 0 & 30 \\
\hline $\mathrm{h}$ & Inovasi dan kreativitas dalam perkuliahan & 0 & 12 & 12 & 6 & 0 & 30 \\
\hline $\mathrm{i}$ & Mengajar sesuai dengan beban kerja dosen & 5 & 16 & 12 & 2 & 0 & 35 \\
\hline $\mathrm{j}$ & Kedisiplinan dalam mengajar & 5 & 20 & 9 & 2 & 0 & 36 \\
\hline $\mathrm{k}$ & Kewibawaan sebagai dosen & 10 & 32 & 0 & 0 & 0 & 42 \\
\hline 1 & Kearifan dalam mengambil keputusan & 0 & 32 & 6 & 0 & 0 & 38 \\
\hline $\mathrm{m}$ & Menjadi teladan dalam sikap dan perilaku & 0 & 40 & 0 & 0 & 0 & 40 \\
\hline $\mathrm{n}$ & $\begin{array}{l}\text { Kemampuan mengendalikan diri dalam berbagai } \\
\text { situasi dan kondisi }\end{array}$ & 10 & 32 & 0 & 0 & 0 & 42 \\
\hline $\mathrm{O}$ & Adil dalam memperlakukan mahasiswa & 0 & 40 & 0 & 0 & 0 & 40 \\
\hline & JUMLAH & & & & & & 551 \\
\hline
\end{tabular}

Berdasarkan Tabel 7 dapat diketahui bahwa jumlah skor kinerja dosen E dalam pendidikan dan pengajaran adalah 551. Berdasarkan rumus, maka skor ketercapaian:

$$
\begin{aligned}
& =(551 / 750) \times 100 \% \\
& =73,47 \%
\end{aligned}
$$

Sesuai dengan kriteria evaluasi yang telah ditetapkan berarti baik. Nilai tertinggi berada pada aspek kinerja kewibawaan sebagai dosen dan kemampuan mengendalikan diri dalam berbagai situasi dan kondisi yaitu 42. Hal ini dimungkinkan karena memiliki kompetensi kepribadian yang baik sedangkan nilai terendah berada pada aspek kinerja memanfaatkan IPTEK dalam perkuliahan serta inovasi dan kreativitas dalam perkuliahan yaitu 30 . Hal ini dimungkinkan karena faktor usia, lebih dari limapuluh tahun sehingga tidak menguasai teknologi dan kurang mengikuti seminar atau diklat untuk peningkatan kompetensi keilmuan dan keahlian. 
Tabel 8. Total Skor Kinerja F dalam Pendidikan dan Pengajaran

\begin{tabular}{|c|c|c|c|c|c|c|c|}
\hline \multirow{2}{*}{ No } & \multirow{2}{*}{ Melaksanakan Pendidikan dan Pengajaran } & \multicolumn{5}{|c|}{ Skor } & \multirow{2}{*}{$\begin{array}{l}\text { Total } \\
\text { Skor }\end{array}$} \\
\hline & & 5 & 4 & 3 & 2 & 1 & \\
\hline $\mathrm{a}$ & Kinerja dalam merencanakan pembelajaran & 35 & 12 & 0 & 0 & 0 & 47 \\
\hline $\mathrm{b}$ & Kinerja dalam melaksanakan pembelajaran & 20 & 20 & 3 & 0 & 0 & 43 \\
\hline $\mathrm{c}$ & Kinerja dalam mengembangkan sumber belajar & 30 & 16 & 0 & 0 & 0 & 46 \\
\hline $\mathrm{d}$ & Kinerja dalam mengevaluasi pembelajaran & 20 & 20 & 3 & 0 & 0 & 43 \\
\hline e & $\begin{array}{l}\text { Kinerja dalam mengaplikasikan berbagai metode } \\
\text { pembelajaran }\end{array}$ & 30 & 16 & 0 & 0 & 0 & 46 \\
\hline $\mathrm{f}$ & Penguasaan materi pembelajaran & 45 & 4 & 0 & 0 & 0 & 49 \\
\hline $\mathrm{g}$ & Kinerja memanfaatkan IPTEK dalam perkuliahan & 15 & 28 & 0 & 0 & 0 & 43 \\
\hline $\mathrm{h}$ & Inovasi dan kreativitas dalam perkuliahan & 10 & 28 & 3 & 0 & 0 & 41 \\
\hline $\mathrm{i}$ & Mengajar sesuai dengan beban kerja dosen & 10 & 24 & 6 & 0 & 0 & 40 \\
\hline $\mathrm{j}$ & Kedisiplinan dalam mengajar & 10 & 24 & 6 & 0 & 0 & 40 \\
\hline $\mathrm{k}$ & Kewibawaan sebagai dosen & 30 & 16 & 0 & 0 & 0 & 46 \\
\hline 1 & Kearifan dalam mengambil keputusan & 10 & 32 & 0 & 0 & 0 & 42 \\
\hline $\mathrm{m}$ & Menjadi teladan dalam sikap dan perilaku & 5 & 32 & 3 & 0 & 0 & 40 \\
\hline $\mathrm{n}$ & $\begin{array}{l}\text { Kemampuan mengendalikan diri dalam berbagai } \\
\text { situasi dan kondisi }\end{array}$ & 0 & 32 & 6 & 0 & 0 & 38 \\
\hline $\mathrm{O}$ & Adil dalam memperlakukan mahasiswa & 10 & 28 & 0 & 1 & 0 & 39 \\
\hline
\end{tabular}

Berdasarkan Tabel 8 dapat diketahui bahwa jumlah skor kinerja dosen $\mathrm{F}$ dalam pendidikan dan pengajaran adalah 643. Berdasarkan rumus, maka skor ketercapaian:

$$
\begin{aligned}
& =(643 / 750) \times 100 \% \\
& =85,73 \%
\end{aligned}
$$

Sesuai dengan kriteria evaluasi yang telah ditetapkan berarti sangat baik. Nilai tertinggi berada pada aspek kinerja penguasaan materi pembelajaran yaitu 49. Hal ini dimungkinkan karena sudah limabelas tahun mengajar dan memiliki kompetensi sesuai bidang keahliannya sedangkan nilai terendah berada pada aspek kemampuan mengendalikan diri dalam berbagai situasi dan kondisi yaitu 38. Hal ini dimungkinkan karena memiliki kompetensi kepribadian yang cukup. 
Tabel 9. Total Skor Kinerja G dalam Pendidikan dan Pengajaran

\begin{tabular}{|c|c|c|c|c|c|c|c|}
\hline \multirow{2}{*}{ No } & \multirow{2}{*}{ Melaksanakan Pendidikan dan Pengajaran } & \multicolumn{5}{|c|}{ Skor } & \multirow{2}{*}{$\begin{array}{l}\text { Total } \\
\text { Skor }\end{array}$} \\
\hline & & 5 & 4 & 3 & 2 & 1 & \\
\hline $\mathrm{a}$ & Kinerja dalam merencanakan pembelajaran & 20 & 24 & 0 & 0 & 0 & 44 \\
\hline $\mathrm{b}$ & Kinerja dalam melaksanakan pembelajaran & 25 & 20 & 0 & 0 & 0 & 45 \\
\hline $\mathrm{c}$ & Kinerja dalam mengembangkan sumber belajar & 15 & 20 & 6 & 0 & 0 & 41 \\
\hline d & Kinerja dalam mengevaluasi pembelajaran & 10 & 24 & 3 & 2 & 0 & 39 \\
\hline e & $\begin{array}{l}\text { Kinerja dalam mengaplikasikan berbagai metode } \\
\text { pembelajaran }\end{array}$ & 5 & 28 & 6 & 0 & 0 & 39 \\
\hline $\mathrm{f}$ & Penguasaan materi pembelajaran & 25 & 16 & 3 & 0 & 0 & 44 \\
\hline $\mathrm{g}$ & Kinerja memanfaatkan IPTEK dalam perkuliahan & 5 & 20 & 12 & 0 & 0 & 37 \\
\hline $\mathrm{h}$ & Inovasi dan kreativitas dalam perkuliahan & 0 & 28 & 9 & 0 & 0 & 37 \\
\hline $\mathrm{i}$ & Mengajar sesuai dengan beban kerja dosen & 25 & 16 & 3 & 0 & 0 & 44 \\
\hline $\mathrm{j}$ & Kedisiplinan dalam mengajar & 40 & 8 & 0 & 0 & 0 & 48 \\
\hline $\mathrm{k}$ & Kewibawaan sebagai dosen & 25 & 20 & 0 & 0 & 0 & 45 \\
\hline 1 & Kearifan dalam mengambil keputusan & 5 & 36 & 0 & 0 & 0 & 41 \\
\hline $\mathrm{m}$ & Menjadi teladan dalam sikap dan perilaku & 10 & 32 & 0 & 0 & 0 & 42 \\
\hline $\mathrm{n}$ & $\begin{array}{l}\text { Kemampuan mengendalikan diri dalam berbagai } \\
\text { situasi dan kondisi }\end{array}$ & 5 & 28 & 6 & 0 & 0 & 39 \\
\hline o & Adil dalam memperlakukan mahasiswa & 15 & 28 & 0 & 0 & 0 & 43 \\
\hline & JUMLAH & & & & & & 628 \\
\hline
\end{tabular}

Berdasarkan Tabel 9 dapat diketahui bahwa jumlah skor kinerja dosen $\mathrm{G}$ dalam pendidikan dan pengajaran adalah 628 . Berdasarkan rumus, maka skor ketercapaian:

$$
\begin{aligned}
& =(628 / 750) \times 100 \% \\
& =83,73 \%
\end{aligned}
$$

Sesuai dengan kriteria evaluasi yang telah ditetapkan berarti sangat baik. Nilai tertinggi berada pada aspek kinerja kedisiplinan dalam mengajar yaitu 48. Hal ini dimungkinkan karena memiliki etos kerja yang tinggi sedangkan nilai terendah berada pada aspek kinerja memanfaatkan IPTEK dalam perkuliahan serta inovasi dan kreativitas dalam perkuliahan yaitu 37. Hal ini dimungkinkan karena selain sebagai dosen tetap juga sebagai dosen dengan tugas tambahan sehingga kurang maksimal dalam dua aspek tersebut. 
Tabel 10. Total Skor Kinerja H dalam Pendidikan dan Pengajaran

\begin{tabular}{|c|l|c|c|c|c|c|c|}
\hline \multirow{2}{*}{ No } & \multicolumn{1}{|c|}{ Melaksanakan Pendidikan dan Pengajaran } & \multicolumn{7}{|c|}{ Skor } & Total \\
\cline { 3 - 8 } & & 5 & 4 & 3 & 2 & 1 & Skor \\
\hline a & Kinerja dalam merencanakan pembelajaran & 30 & 16 & 0 & 0 & 0 & 46 \\
\hline b & Kinerja dalam melaksanakan pembelajaran & 15 & 20 & 3 & 2 & 0 & 40 \\
\hline c & Kinerja dalam mengembangkan sumber belajar & 35 & 8 & 3 & 0 & 0 & 46 \\
\hline d & Kinerja dalam mengevaluasi pembelajaran & 0 & 28 & 9 & 0 & 0 & 37 \\
\hline e & $\begin{array}{l}\text { Kinerja dalam mengaplikasikan berbagai metode } \\
\text { pembelajaran }\end{array}$ & 10 & 24 & 6 & 0 & 0 & 40 \\
\hline f & Penguasaan materi pembelajaran & 35 & 12 & 0 & 0 & 0 & 47 \\
\hline g & Kinerja memanfaatkan IPTEK dalam perkuliahan & 10 & 28 & 3 & 0 & 0 & 41 \\
\hline h & Inovasi dan kreativitas dalam perkuliahan & 15 & 16 & 9 & 0 & 0 & 40 \\
\hline i & Mengajar sesuai dengan beban kerja dosen & 15 & 12 & 12 & 0 & 0 & 39 \\
\hline j & Kedisiplinan dalam mengajar & 10 & 20 & 9 & 0 & 0 & 39 \\
\hline k & Kewibawaan sebagai dosen & 15 & 28 & 0 & 0 & 0 & 43 \\
\hline l & Kearifan dalam mengambil keputusan & 10 & 28 & 3 & 0 & 0 & 41 \\
\hline m & Menjadi teladan dalam sikap dan perilaku & 15 & 24 & 3 & 0 & 0 & 42 \\
\hline \multirow{2}{*}{$\mathrm{n}$} & $\begin{array}{l}\text { Kemampuan mengendalikan diri dalam berbagai } \\
\text { situasi dan kondisi }\end{array}$ & 0 & 36 & 3 & 0 & 0 & 39 \\
\hline o & Adil dalam memperlakukan mahasiswa & 15 & 28 & 0 & 0 & 0 & 43 \\
\hline & \multicolumn{1}{|c|}{ JUMLAH } \\
\hline
\end{tabular}

Berdasarkan Tabel 10 dapat diketahui bahwa jumlah skor kinerja dosen $\mathrm{H}$ dalam pendidikan dan pengajaran adalah 623. Berdasarkan rumus, maka skor ketercapaian:

$$
\begin{aligned}
& =(623 / 750) \times 100 \% \\
& =83,07 \%
\end{aligned}
$$

Sesuai dengan kriteria evaluasi yang telah ditetapkan berarti sangat baik. Nilai tertinggi berada pada aspek kinerja penguasaan materi pembelajaran yaitu 47. Hal ini dimungkinkan karena memiliki kompetensi di bidangnya sedangkan nilai terendah berada pada aspek kinerja dalam mengevaluasi pembelajaran yaitu 37. Hal ini dimungkinkan karena belum sepenuhnya menerapkan jenis-jenis evaluasi pembelajaran.

\begin{tabular}{|c|c|c|c|c|c|c|c|}
\hline \multirow{2}{*}{ No } & \multirow{2}{*}{ Melaksanakan Pendidikan dan Pengajaran } & \multicolumn{5}{|c|}{ Skor } & \multirow{2}{*}{$\begin{array}{l}\text { Total } \\
\text { Skor }\end{array}$} \\
\hline & & 5 & 4 & 3 & 2 & 1 & \\
\hline $\mathrm{a}$ & Kinerja dalam merencanakan pembelajaran & 20 & 24 & 0 & 0 & 0 & 44 \\
\hline $\mathrm{b}$ & Kinerja dalam melaksanakan pembelajaran & 25 & 20 & 0 & 0 & 0 & 45 \\
\hline $\mathrm{c}$ & Kinerja dalam mengembangkan sumber belajar & 30 & 8 & 6 & 0 & 0 & 44 \\
\hline $\mathrm{d}$ & Kinerja dalam mengevaluasi pembelajaran & 10 & 16 & 9 & 2 & 0 & 37 \\
\hline $\mathrm{e}$ & $\begin{array}{l}\text { Kinerja dalam mengaplikasikan berbagai metode } \\
\text { pembelajaran }\end{array}$ & 15 & 24 & 3 & 0 & 0 & 42 \\
\hline $\mathrm{f}$ & Penguasaan materi pembelajaran & 25 & 16 & 3 & 0 & 0 & 44 \\
\hline $\mathrm{g}$ & Kinerja memanfaatkan IPTEK dalam perkuliahan & 10 & 24 & 6 & 0 & 0 & 40 \\
\hline $\mathrm{h}$ & Inovasi dan kreativitas dalam perkuliahan & 10 & 16 & 12 & 0 & 0 & 38 \\
\hline $\mathrm{i}$ & Mengajar sesuai dengan beban kerja dosen & 10 & 20 & 9 & 0 & 0 & 39 \\
\hline $\mathrm{j}$ & Kedisiplinan dalam mengajar & 10 & 28 & 3 & 0 & 0 & 41 \\
\hline $\mathrm{k}$ & Kewibawaan sebagai dosen & 25 & 20 & 0 & 0 & 0 & 45 \\
\hline 1 & Kearifan dalam mengambil keputusan & 0 & 40 & 0 & 0 & 0 & 40 \\
\hline $\mathrm{m}$ & Menjadi teladan dalam sikap dan perilaku & 0 & 40 & 0 & 0 & 0 & 40 \\
\hline $\mathrm{n}$ & $\begin{array}{l}\text { Kemampuan mengendalikan diri dalam berbagai } \\
\text { situasi dan kondisi }\end{array}$ & 0 & 40 & 0 & 0 & 0 & 40 \\
\hline $\mathrm{o}$ & Adil dalam memperlakukan mahasiswa & 25 & 20 & 0 & 0 & 0 & 45 \\
\hline & JUMLAH & & & & & & 624 \\
\hline
\end{tabular}

Tabel 11. Total Skor Kinerja I dalam Pendidikan dan Pengajaran 
Berdasarkan Tabel 11 dapat diketahui bahwa jumlah skor kinerja dosen I dalam pendidikan dan pengajaran adalah 624. Berdasarkan rumus, maka skor ketercapaian:

$$
\begin{aligned}
& =(624 / 750) \times 100 \% \\
& =83,2 \%
\end{aligned}
$$

Sesuai dengan kriteria evaluasi yang telah ditetapkan berarti sangat baik. Nilai tertinggi berada pada aspek kinerja dalam melaksanakan pembelajaran, kewibawaan sebagai dosen dan adil dalam memperlakukan mahasiswa yaitu 45. Hal ini dimungkinkan karena memiliki kompetensi pedagogik dan kepribadian yang sangat baik sedangkan nilai terendah berada pada aspek kinerja dalam mengevaluasi pembelajaran yaitu 37. Hal ini dimungkinkan karena belum sepenuhnya menerapkan jenis-jenis evaluasi pembelajaran.

Tabel 12. Total Skor Kinerja J dalam Pendidikan dan Pengajaran

\begin{tabular}{|c|l|c|c|c|c|c|c|}
\hline \multirow{2}{*}{ No } & \multicolumn{1}{|}{ Melaksanakan Pendidikan dan Pengajaran } & \multicolumn{4}{c|}{ Skor } & Total \\
\cline { 3 - 6 } & & 5 & 4 & 3 & 2 & 1 & Skor \\
\hline a & Kinerja dalam merencanakan pembelajaran & 5 & 24 & 9 & 0 & 0 & 38 \\
\hline b & Kinerja dalam melaksanakan pembelajaran & 5 & 28 & 6 & 0 & 0 & 39 \\
\hline c & Kinerja dalam mengembangkan sumber belajar & 0 & 12 & 18 & 2 & 0 & 32 \\
\hline d & Kinerja dalam mengevaluasi pembelajaran & 0 & 12 & 21 & 0 & 0 & 33 \\
\hline e & $\begin{array}{l}\text { Kinerja dalam mengaplikasikan berbagai metode } \\
\text { pembelajaran }\end{array}$ & 0 & 16 & 15 & 2 & 0 & 33 \\
\hline f & Penguasaan materi pembelajaran & 20 & 24 & 0 & 0 & 0 & 44 \\
\hline g & Kinerja memanfaatkan IPTEK dalam perkuliahan & 0 & 8 & 21 & 2 & 0 & 31 \\
\hline h & Inovasi dan kreativitas dalam perkuliahan & 0 & 0 & 24 & 4 & 0 & 28 \\
\hline i & Mengajar sesuai dengan beban kerja dosen & 0 & 36 & 3 & 0 & 0 & 39 \\
\hline j & Kedisiplinan dalam mengajar & 20 & 24 & 0 & 0 & 0 & 44 \\
\hline k & Kewibawaan sebagai dosen & 25 & 20 & 0 & 0 & 0 & 45 \\
\hline l & Kearifan dalam mengambil keputusan & 0 & 40 & 0 & 0 & 0 & 40 \\
\hline m & Menjadi teladan dalam sikap dan perilaku & 0 & 40 & 0 & 0 & 0 & 40 \\
\hline n & $\begin{array}{l}\text { Kemampuan mengendalikan diri dalam berbagai } \\
\text { situasi dan kondisi }\end{array}$ & 0 & 40 & 0 & 0 & 0 & 40 \\
\hline o & Adil dalam memperlakukan mahasiswa & 25 & 20 & 0 & 0 & 0 & 45 \\
\hline & & & & & 571 \\
\hline
\end{tabular}

Berdasarkan Tabel 12 dapat diketahui bahwa jumlah skor kinerja dosen J dalam pendidikan dan pengajaran adalah 571. Berdasarkan rumus, maka skor ketercapaian:

$=(571 / 750) \times 100 \%$

$=76,13 \%$

Sesuai dengan kriteria evaluasi yang telah ditetapkan berarti baik. Nilai tertinggi berada pada aspek kinerja kewibawaan sebagai dosen dan adil dalam memperlakukan mahasiswa yaitu 45. Hal ini dimungkinkan karena memiliki kompetensi kepribadian yang baik sedangkan nilai terendah berada pada aspek kinerja inovasi dan kreativitas dalam perkuliahan yaitu 28 . Hal ini dimungkinkan karena masa kerja masih di bawah lima tahun sehingga masih kurang berpengalaman dalam hal inovasi dan kreativitas dalam mengajar. 
Tabel 13. Total Skor Kinerja K dalam Pendidikan dan Pengajaran

\begin{tabular}{|c|c|c|c|c|c|c|c|}
\hline \multirow{2}{*}{ No } & \multirow{2}{*}{ Melaksanakan Pendidikan dan Pengajaran } & \multicolumn{5}{|c|}{ Skor } & \multirow{2}{*}{$\begin{array}{l}\text { Total } \\
\text { Skor }\end{array}$} \\
\hline & & 5 & 4 & 3 & 2 & 1 & \\
\hline $\mathrm{a}$ & Kinerja dalam merencanakan pembelajaran & 0 & 24 & 12 & 0 & 0 & 36 \\
\hline $\mathrm{b}$ & Kinerja dalam melaksanakan pembelajaran & 5 & 28 & 6 & 0 & 0 & 39 \\
\hline $\mathrm{c}$ & Kinerja dalam mengembangkan sumber belajar & 0 & 28 & 9 & 0 & 0 & 37 \\
\hline $\mathrm{d}$ & Kinerja dalam mengevaluasi pembelajaran & 0 & 16 & 18 & 0 & 0 & 34 \\
\hline $\mathrm{e}$ & $\begin{array}{l}\text { Kinerja dalam mengaplikasikan berbagai metode } \\
\text { pembelajaran }\end{array}$ & 0 & 28 & 9 & 0 & 0 & 37 \\
\hline $\mathrm{f}$ & Penguasaan materi pembelajaran & 20 & 16 & 6 & 0 & 0 & 42 \\
\hline $\mathrm{g}$ & Kinerja memanfaatkan IPTEK dalam perkuliahan & 0 & 4 & 27 & 0 & 0 & 31 \\
\hline $\mathrm{h}$ & Inovasi dan kreativitas dalam perkuliahan & 0 & 4 & 24 & 2 & 0 & 30 \\
\hline $\mathrm{i}$ & Mengajar sesuai dengan beban kerja dosen & 0 & 32 & 6 & 0 & 0 & 38 \\
\hline $\mathrm{j}$ & Kedisiplinan dalam mengajar & 20 & 24 & 0 & 0 & 0 & 44 \\
\hline $\mathrm{k}$ & Kewibawaan sebagai dosen & 25 & 20 & 0 & 0 & 0 & 45 \\
\hline 1 & Kearifan dalam mengambil keputusan & 0 & 40 & 0 & 0 & 0 & 40 \\
\hline $\mathrm{m}$ & Menjadi teladan dalam sikap dan perilaku & 0 & 40 & 0 & 0 & 0 & 40 \\
\hline $\mathrm{n}$ & $\begin{array}{l}\text { Kemampuan mengendalikan diri dalam berbagai } \\
\text { situasi dan kondisi }\end{array}$ & 0 & 40 & 0 & 0 & 0 & 40 \\
\hline o & Adil dalam memperlakukan mahasiswa & 25 & 20 & 0 & 0 & 0 & 45 \\
\hline & JUMLAH & & & & & & 578 \\
\hline
\end{tabular}

Berdasarkan Tabel 13 dapat diketahui bahwa jumlah skor kinerja dosen K dalam pendidikan dan pengajaran adalah 578. Berdasarkan rumus, maka skor ketercapaian:

$$
\begin{aligned}
& =(578 / 750) \times 100 \% \\
& =77,07 \%
\end{aligned}
$$

Sesuai dengan kriteria evaluasi yang telah ditetapkan berarti baik. Nilai tertinggi berada pada aspek kinerja kewibawaan sebagai dosen dan adil dalam memperlakukan mahasiswa yaitu 45. Hal ini dimungkinkan karena memiliki kompetensi kepribadian yang baik sedangkan nilai terendah berada pada aspek kinerja inovasi dan kreativitas dalam perkuliahan yaitu 30 . Hal ini dimungkinkan karena masa kerja masih di bawah lima tahun sehingga masih kurang berpengalaman dalam hal inovasi dan kreativitas dalam mengajar. 
Tabel 14. Total Skor Kinerja L dalam Pendidikan dan Pengajaran

\begin{tabular}{|c|l|c|c|c|c|c|c|}
\hline \multirow{2}{*}{ No } & \multicolumn{2}{|}{ Melaksanakan Pendidikan dan Pengajaran } & \multicolumn{4}{c|}{$\begin{array}{c}\text { Total } \\
\text { Skor }\end{array}$} \\
\cline { 3 - 5 } & & 5 & 4 & 3 & 2 & 1 & Skor \\
\hline a & Kinerja dalam merencanakan pembelajaran & 15 & 28 & 0 & 0 & 0 & 43 \\
\hline b & Kinerja dalam melaksanakan pembelajaran & 15 & 20 & 6 & 0 & 0 & 41 \\
\hline c & Kinerja dalam mengembangkan sumber belajar & 10 & 20 & 9 & 0 & 0 & 39 \\
\hline d & Kinerja dalam mengevaluasi pembelajaran & 5 & 20 & 12 & 0 & 0 & 37 \\
\hline e & $\begin{array}{l}\text { Kinerja dalam mengaplikasikan berbagai metode } \\
\text { pembelajaran }\end{array}$ & 20 & 20 & 3 & 0 & 0 & 43 \\
\hline f & Penguasaan materi pembelajaran & 35 & 12 & 0 & 0 & 0 & 47 \\
\hline g & Kinerja memanfaatkan IPTEK dalam perkuliahan & 5 & 20 & 12 & 0 & 0 & 37 \\
\hline h & Inovasi dan kreativitas dalam perkuliahan & 5 & 20 & 9 & 2 & 0 & 36 \\
\hline i & Mengajar sesuai dengan beban kerja dosen & 10 & 28 & 3 & 0 & 0 & 41 \\
\hline j & Kedisiplinan dalam mengajar & 5 & 24 & 9 & 0 & 0 & 38 \\
\hline k & Kewibawaan sebagai dosen & 25 & 20 & 0 & 0 & 0 & 45 \\
\hline l & Kearifan dalam mengambil keputusan & 30 & 16 & 0 & 0 & 0 & 46 \\
\hline m & Menjadi teladan dalam sikap dan perilaku & 20 & 24 & 0 & 0 & 0 & 44 \\
\hline n & $\begin{array}{l}\text { Kemampuan mengendalikan diri dalam berbagai } \\
\text { situasi dan kondisi }\end{array}$ & 10 & 32 & 0 & 0 & 0 & 42 \\
\hline o & Adil dalam memperlakukan mahasiswa & 10 & 32 & 0 & 0 & 0 & 42 \\
\hline
\end{tabular}

Berdasarkan Tabel 14 dapat diketahui bahwa jumlah skor kinerja dosen L dalam pendidikan dan pengajaran adalah 621 . Berdasarkan rumus, maka skor ketercapaian:

$$
\begin{aligned}
& =(621 / 750) \times 100 \% \\
& =82,8 \%
\end{aligned}
$$

Sesuai dengan kriteria evaluasi yang telah ditetapkan berarti sangat baik. Nilai tertinggi berada pada aspek kinerja penguasaan materi pembelajaran yaitu 47. Hal ini dimungkinkan karena memiliki kompetensi di bidangnya sedangkan nilai terendah berada pada aspek kinerja inovasi dan kreativitas dalam perkuliahan yaitu 36. Hal ini dimungkinkan karena selain sebagai dosen tetap juga sebagai dosen dengan tugas tambahan dan tugas di organisasi keagamaan sehingga kurang maksimal dalam hal inovasi dan kreativitas. 
Tabel 15. Total Skor Kinerja M dalam Pendidikan dan Pengajaran

\begin{tabular}{|c|l|c|c|c|c|c|c|}
\hline \multirow{2}{*}{ No } & \multicolumn{2}{|}{ Melaksanakan Pendidikan dan Pengajaran } & \multicolumn{4}{c|}{ Skor } & Total \\
\cline { 3 - 6 } & & 5 & 4 & 3 & 2 & 1 & Skor \\
\hline a & Kinerja dalam merencanakan pembelajaran & 5 & 24 & 9 & 0 & 0 & 38 \\
\hline b & Kinerja dalam melaksanakan pembelajaran & 0 & 32 & 6 & 0 & 0 & 38 \\
\hline c & Kinerja dalam mengembangkan sumber belajar & 20 & 8 & 12 & 0 & 0 & 40 \\
\hline d & Kinerja dalam mengevaluasi pembelajaran & 5 & 24 & 9 & 0 & 0 & 38 \\
\hline e & $\begin{array}{l}\text { Kinerja dalam mengaplikasikan berbagai metode } \\
\text { pembelajaran }\end{array}$ & 15 & 16 & 6 & 2 & 0 & 39 \\
\hline f & Penguasaan materi pembelajaran & 15 & 24 & 0 & 2 & 0 & 41 \\
\hline g & Kinerja memanfaatkan IPTEK dalam perkuliahan & 10 & 20 & 9 & 0 & 0 & 39 \\
\hline h & Inovasi dan kreativitas dalam perkuliahan & 10 & 12 & 12 & 2 & 0 & 36 \\
\hline i & Mengajar sesuai dengan beban kerja dosen & 0 & 28 & 6 & 2 & 0 & 36 \\
\hline j & Kedisiplinan dalam mengajar & 5 & 12 & 15 & 2 & 0 & 34 \\
\hline k & Kewibawaan sebagai dosen & 5 & 36 & 0 & 0 & 0 & 41 \\
\hline l & Kearifan dalam mengambil keputusan & 10 & 28 & 3 & 0 & 0 & 41 \\
\hline m & Menjadi teladan dalam sikap dan perilaku & 10 & 24 & 6 & 0 & 0 & 40 \\
\hline n & $\begin{array}{l}\text { Kemampuan mengendalikan diri dalam berbagai } \\
\text { situasi dan kondisi }\end{array}$ & 20 & 24 & 0 & 0 & 0 & 44 \\
\hline o & Adil dalam memperlakukan mahasiswa & 25 & 20 & 0 & 0 & 0 & 45 \\
\hline & & & & & 590 \\
\hline
\end{tabular}

Berdasarkan Tabel 15 dapat diketahui bahwa jumlah skor kinerja dosen M dalam pendidikan dan pengajaran adalah 590. Berdasarkan rumus, maka skor ketercapaian:

$$
\begin{aligned}
& =(590 / 750) \times 100 \% \\
& =78,67 \%
\end{aligned}
$$

Sesuai dengan kriteria evaluasi yang telah ditetapkan berarti baik. Nilai tertinggi berada pada aspek kinerja adil dalam memperlakukan mahasiswa yaitu 45. Hal ini dimungkinkan karena memiliki kompetensi kepribadian yang baik sedangkan nilai terendah berada pada aspek kedisiplinan dalam mengajar yaitu 34. Hal ini dimungkinkan karena kurangnya etos kerja. 
Tabel 16. Total Skor Kinerja N dalam Pendidikan dan Pengajaran

\begin{tabular}{|c|l|c|c|c|c|c|c|}
\hline \multirow{2}{*}{ No } & \multicolumn{2}{|}{ Melaksanakan Pendidikan dan Pengajaran } & \multicolumn{5}{c|}{$\begin{array}{c}\text { Total } \\
\text { Skor }\end{array}$} \\
\cline { 3 - 5 } & & 5 & 4 & 3 & 2 & 1 & Skor \\
\hline a & Kinerja dalam merencanakan pembelajaran & 25 & 20 & 0 & 0 & 0 & 45 \\
\hline b & Kinerja dalam melaksanakan pembelajaran & 20 & 24 & 0 & 0 & 0 & 44 \\
\hline c & Kinerja dalam mengembangkan sumber belajar & 20 & 20 & 3 & 0 & 0 & 43 \\
\hline d & Kinerja dalam mengevaluasi pembelajaran & 10 & 24 & 6 & 0 & 0 & 40 \\
\hline e & $\begin{array}{l}\text { Kinerja dalam mengaplikasikan berbagai metode } \\
\text { pembelajaran }\end{array}$ & 10 & 32 & 0 & 0 & 0 & 42 \\
\hline f & Penguasaan materi pembelajaran & 20 & 24 & 0 & 0 & 0 & 44 \\
\hline g & Kinerja memanfaatkan IPTEK dalam perkuliahan & 15 & 24 & 3 & 0 & 0 & 42 \\
\hline h & Inovasi dan kreativitas dalam perkuliahan & 10 & 16 & 12 & 0 & 0 & 38 \\
\hline i & Mengajar sesuai dengan beban kerja dosen & 5 & 32 & 3 & 0 & 0 & 40 \\
\hline j & Kedisiplinan dalam mengajar & 20 & 24 & 0 & 0 & 0 & 44 \\
\hline k & Kewibawaan sebagai dosen & 30 & 16 & 0 & 0 & 0 & 46 \\
\hline l & Kearifan dalam mengambil keputusan & 5 & 36 & 0 & 0 & 0 & 41 \\
\hline m & Menjadi teladan dalam sikap dan perilaku & 20 & 24 & 0 & 0 & 0 & 44 \\
\hline n & $\begin{array}{l}\text { Kemampuan mengendalikan diri dalam berbagai } \\
\text { situasi dan kondisi }\end{array}$ & 10 & 32 & 0 & 0 & 0 & 42 \\
\hline o & Adil dalam memperlakukan mahasiswa & 40 & 8 & 0 & 0 & 0 & 48 \\
\hline
\end{tabular}

Berdasarkan Tabel 16 dapat diketahui bahwa jumlah skor kinerja dosen $\mathrm{N}$ dalam pendidikan dan pengajaran adalah 643. Berdasarkan rumus, maka skor ketercapaian:

$$
\begin{aligned}
& =(643 / 750) \times 100 \% \\
& =85,73 \%
\end{aligned}
$$

Sesuai dengan kriteria evaluasi yang telah ditetapkan berarti sangat baik. Nilai tertinggi berada pada aspek kinerja adil dalam memperlakukan mahasiswa yaitu 48. Hal ini dimungkinkan karena memiliki kompetensi kepribadian yang sangat baik sedangkan nilai terendah berada pada aspek inovasi dan kreativitas dalam perkuliahan yaitu 38 . Hal ini dimungkinkan karena kurang mengikuti seminar atau diklat untuk peningkatan kompetensi keilmuan dan keahlian. 
Tabel 17. Total Skor Kinerja O dalam Pendidikan dan Pengajaran

\begin{tabular}{|c|c|c|c|c|c|c|c|}
\hline \multirow{2}{*}{ No } & \multirow{2}{*}{ Melaksanakan Pendidikan dan Pengajaran } & \multicolumn{5}{|c|}{ Skor } & \multirow{2}{*}{$\begin{array}{l}\text { Total } \\
\text { Skor }\end{array}$} \\
\hline & & 5 & 4 & 3 & 2 & 1 & \\
\hline $\mathrm{a}$ & Kinerja dalam merencanakan pembelajaran & 20 & 24 & 0 & 0 & 0 & 44 \\
\hline $\mathrm{b}$ & Kinerja dalam melaksanakan pembelajaran & 15 & 28 & 0 & 0 & 0 & 43 \\
\hline $\mathrm{c}$ & Kinerja dalam mengembangkan sumber belajar & 10 & 32 & 0 & 0 & 0 & 42 \\
\hline $\mathrm{d}$ & Kinerja dalam mengevaluasi pembelajaran & 5 & 36 & 0 & 0 & 0 & 41 \\
\hline $\mathrm{e}$ & $\begin{array}{l}\text { Kinerja dalam mengaplikasikan berbagai metode } \\
\text { pembelajaran }\end{array}$ & 15 & 28 & 0 & 0 & 0 & 43 \\
\hline $\mathrm{f}$ & Penguasaan materi pembelajaran & 30 & 12 & 3 & 0 & 0 & 45 \\
\hline $\mathrm{g}$ & Kinerja memanfaatkan IPTEK dalam perkuliahan & 10 & 28 & 3 & 0 & 0 & 41 \\
\hline $\mathrm{h}$ & Inovasi dan kreativitas dalam perkuliahan & 15 & 20 & 6 & 0 & 0 & 41 \\
\hline $\mathrm{i}$ & Mengajar sesuai dengan beban kerja dosen & 10 & 32 & 0 & 0 & 0 & 42 \\
\hline $\mathrm{j}$ & Kedisiplinan dalam mengajar & 20 & 20 & 3 & 0 & 0 & 43 \\
\hline $\mathrm{k}$ & Kewibawaan sebagai dosen & 30 & 16 & 0 & 0 & 0 & 46 \\
\hline 1 & Kearifan dalam mengambil keputusan & 5 & 36 & 0 & 0 & 0 & 41 \\
\hline $\mathrm{m}$ & Menjadi teladan dalam sikap dan perilaku & 10 & 32 & 0 & 0 & 0 & 42 \\
\hline $\mathrm{n}$ & $\begin{array}{l}\text { Kemampuan mengendalikan diri dalam berbagai } \\
\text { situasi dan kondisi }\end{array}$ & 10 & 32 & 0 & 0 & 0 & 42 \\
\hline o & Adil dalam memperlakukan mahasiswa & 40 & 8 & 0 & 0 & 0 & 48 \\
\hline & JUMLAH & & & & & & 644 \\
\hline
\end{tabular}

Berdasarkan Tabel 17 dapat diketahui bahwa jumlah skor kinerja dosen O dalam pendidikan dan pengajaran adalah 644 . Berdasarkan rumus, maka skor ketercapaian:

$$
\begin{aligned}
& =(644 / 750) \times 100 \% \\
& =85,87 \%
\end{aligned}
$$

Sesuai dengan kriteria evaluasi yang telah ditetapkan berarti sangat baik. Nilai tertinggi berada pada aspek kinerja adil dalam memperlakukan mahasiswa yaitu 48. Hal ini dimungkinkan karena memiliki kompetensi kepribadian yang sangat baik sedangkan nilai terendah berada pada aspek kinerja dalam mengevaluasi pembelajaran, memanfaatkan IPTEK dalam perkuliahan serta inovasi dan kreativitas dalam perkuliahan yaitu 41. Hal ini dimungkinkan karena kurang mengikuti seminar atau diklat untuk peningkatan kompetensi keilmuan dan keahlian. 
Tabel 18. Total Skor Kinerja P dalam Pendidikan dan Pengajaran

\begin{tabular}{|c|c|c|c|c|c|c|c|}
\hline \multirow{2}{*}{ No } & \multirow{2}{*}{ Melaksanakan Pendidikan dan Pengajaran } & \multicolumn{5}{|c|}{ Skor } & \multirow{2}{*}{$\begin{array}{l}\text { Total } \\
\text { Skor }\end{array}$} \\
\hline & & 5 & 4 & 3 & 2 & 1 & \\
\hline $\mathrm{a}$ & Kinerja dalam merencanakan pembelajaran & 5 & 28 & 6 & 0 & 0 & 39 \\
\hline $\mathrm{b}$ & Kinerja dalam melaksanakan pembelajaran & 5 & 16 & 15 & 0 & 0 & 36 \\
\hline $\mathrm{c}$ & Kinerja dalam mengembangkan sumber belajar & 0 & 28 & 9 & 0 & 0 & 37 \\
\hline $\mathrm{d}$ & Kinerja dalam mengevaluasi pembelajaran & 5 & 20 & 12 & 0 & 0 & 37 \\
\hline $\mathrm{e}$ & $\begin{array}{l}\text { Kinerja dalam mengaplikasikan berbagai metode } \\
\text { pembelajaran }\end{array}$ & 5 & 28 & 6 & 0 & 0 & 39 \\
\hline $\mathrm{f}$ & Penguasaan materi pembelajaran & 5 & 28 & 6 & 0 & 0 & 39 \\
\hline $\mathrm{g}$ & Kinerja memanfaatkan IPTEK dalam perkuliahan & 25 & 20 & 0 & 0 & 0 & 45 \\
\hline $\mathrm{h}$ & Inovasi dan kreativitas dalam perkuliahan & 5 & 8 & 15 & 4 & 0 & 32 \\
\hline $\mathrm{i}$ & Mengajar sesuai dengan beban kerja dosen & 30 & 16 & 0 & 0 & 0 & 46 \\
\hline $\mathrm{j}$ & Kedisiplinan dalam mengajar & 5 & 24 & 9 & 0 & 0 & 38 \\
\hline $\mathrm{k}$ & Kewibawaan sebagai dosen & 25 & 20 & 0 & 0 & 0 & 45 \\
\hline 1 & Kearifan dalam mengambil keputusan & 5 & 36 & 0 & 0 & 0 & 41 \\
\hline $\mathrm{m}$ & Menjadi teladan dalam sikap dan perilaku & 10 & 32 & 0 & 0 & 0 & 42 \\
\hline $\mathrm{n}$ & $\begin{array}{l}\text { Kemampuan mengendalikan diri dalam berbagai } \\
\text { situasi dan kondisi }\end{array}$ & 5 & 36 & 0 & 0 & 0 & 41 \\
\hline $\mathrm{O}$ & Adil dalam memperlakukan mahasiswa & 30 & 16 & 0 & 0 & 0 & 46 \\
\hline & JUMLAH & & & & & & 603 \\
\hline
\end{tabular}

Berdasarkan Tabel 18 dapat diketahui bahwa jumlah skor kinerja dosen P dalam pendidikan dan pengajaran adalah 603 . Berdasarkan rumus, maka skor ketercapaian:

$$
\begin{aligned}
& =(603 / 750) \times 100 \% \\
& =80,4 \%
\end{aligned}
$$

Sesuai dengan kriteria evaluasi yang telah ditetapkan berarti baik. Nilai tertinggi berada pada aspek kinerja mengajar sesuai dengan BKD dan adil dalam memperlakukan mahasiswa yaitu 46. Hal ini dimungkinkan karena sebagai dosen tetap mengikuti ketentuan yang berlaku dan memiliki kompetensi kepribadian yang baik sedangkan nilai terendah berada pada aspek inovasi dan kreativitas dalam perkuliahan yaitu 32. Hal ini dimungkinkan karena kurang mengikuti seminar atau diklat untuk peningkatan kompetensi keilmuan dan keahlian. 
Tabel 19. Total Skor Kinerja Q dalam Pendidikan dan Pengajaran

\begin{tabular}{|c|l|c|c|c|c|c|c|}
\hline \multirow{2}{*}{ No } & \multicolumn{1}{|}{ Melaksanakan Pendidikan dan Pengajaran } & \multicolumn{4}{c|}{ Skor } & Total \\
\cline { 3 - 6 } & & 5 & 4 & 3 & 2 & 1 & Skor \\
\hline a & Kinerja dalam merencanakan pembelajaran & 5 & 28 & 6 & 0 & 0 & 39 \\
\hline b & Kinerja dalam melaksanakan pembelajaran & 0 & 40 & 0 & 0 & 0 & 40 \\
\hline c & Kinerja dalam mengembangkan sumber belajar & 20 & 12 & 9 & 0 & 0 & 41 \\
\hline d & Kinerja dalam mengevaluasi pembelajaran & 15 & 12 & 12 & 0 & 0 & 39 \\
\hline e & $\begin{array}{l}\text { Kinerja dalam mengaplikasikan berbagai metode } \\
\text { pembelajaran }\end{array}$ & 15 & 20 & 6 & 0 & 0 & 41 \\
\hline f & Penguasaan materi pembelajaran & 25 & 20 & 0 & 0 & 0 & 45 \\
\hline g & Kinerja memanfaatkan IPTEK dalam perkuliahan & 0 & 12 & 21 & 0 & 0 & 33 \\
\hline h & Inovasi dan kreativitas dalam perkuliahan & 0 & 8 & 15 & 6 & 0 & 29 \\
\hline i & Mengajar sesuai dengan beban kerja dosen & 0 & 24 & 12 & 0 & 0 & 36 \\
\hline j & Kedisiplinan dalam mengajar & 10 & 32 & 0 & 0 & 0 & 42 \\
\hline k & Kewibawaan sebagai dosen & 0 & 40 & 0 & 0 & 0 & 40 \\
\hline l & Kearifan dalam mengambil keputusan & 5 & 36 & 0 & 0 & 0 & 41 \\
\hline m & Menjadi teladan dalam sikap dan perilaku & 25 & 20 & 0 & 0 & 0 & 45 \\
\hline n & $\begin{array}{l}\text { Kemampuan mengendalikan diri dalam berbagai } \\
\text { situasi dan kondisi }\end{array}$ & 10 & 32 & 0 & 0 & 0 & 42 \\
\hline o & Adil dalam memperlakukan mahasiswa & 25 & 20 & 0 & 0 & 0 & 45 \\
\hline & & & & & 598 \\
\hline
\end{tabular}

Berdasarkan Tabel 19 dapat diketahui bahwa jumlah skor kinerja dosen Q dalam pendidikan dan pengajaran adalah 598. Berdasarkan rumus, maka skor ketercapaian:

$$
\begin{aligned}
& =(598 / 750) \times 100 \% \\
& =79,73 \%
\end{aligned}
$$

Sesuai dengan kriteria evaluasi yang telah ditetapkan berarti baik. Nilai tertinggi berada pada aspek penguasaan materi pembelajaran, menjadi teladan dalam sikap dan perilaku serta adil

dalam memperlakukan mahasiswa yaitu 45. Hal ini dimungkinkan karena memiliki kompetensi profesional dan kepribadian yang baik sedangkan nilai terendah berada pada aspek inovasi dan kreativitas dalam perkuliahan yaitu 29. Hal ini dimungkinkan karena kurang mengikuti seminar atau diklat untuk peningkatan kompetensi keilmuan dan keahlian.

Berdasarkan hasil analisis data kinerja tujuh belas dosen (A-Q) di atas, dalam pendidikan dan pengajaran, maka dapat dibuat rekapan persentase rata-rata sebagai berikut: 
Tabel 20. Persentase Skor Kinerja Dosen dalam Pendidikan dan Pengajaran

\begin{tabular}{|c|c|c|c|c|}
\hline PRODI & DOSEN & SKOR (\%) & RATA-RATA & KRITERIA \\
\hline \multirow{5}{*}{ Teologi } & $\mathrm{A}$ & 82,27 & \multirow{5}{*}{$78,32 \%$} & \multirow{5}{*}{ Baik } \\
\hline & $\mathrm{B}$ & 77,2 & & \\
\hline & $\mathrm{C}$ & 78 & & \\
\hline & $\mathrm{D}$ & 80,67 & & \\
\hline & $\mathrm{E}$ & 73,47 & & \\
\hline \multirow{6}{*}{ PAK } & $\mathrm{F}$ & 85,73 & \multirow{6}{*}{$81,49 \%$} & \multirow{6}{*}{ Sangat Baik } \\
\hline & $\mathrm{G}$ & 83,73 & & \\
\hline & $\mathrm{H}$ & 83,07 & & \\
\hline & I & 83,2 & & \\
\hline & $\mathrm{J}$ & 76,13 & & \\
\hline & $\mathrm{K}$ & 77,07 & & \\
\hline \multirow{6}{*}{$\begin{array}{c}\text { Magister } \\
\text { Teologi }\end{array}$} & $\mathrm{L}$ & 82,8 & \multirow{6}{*}{$82,2 \%$} & \multirow{6}{*}{ Sangat Baik } \\
\hline & $\mathrm{M}$ & 78,67 & & \\
\hline & $\mathrm{N}$ & 85,73 & & \\
\hline & $\mathrm{O}$ & 85,86 & & \\
\hline & $\mathrm{P}$ & 80,4 & & \\
\hline & $\mathrm{Q}$ & 79,73 & & \\
\hline
\end{tabular}

\section{KESIMPULAN}

Kinerja dosen STA Jember dalam melaksanakan pendidikan dan pengajaran adalah baik. Dari hasil wawancara, observasi dan dokumentasi juga menunjukkan bahwa kinerja dosen STA Jember dalam melaksanakan pendidikan dan pengajaran adalah baik, mulai dari merencanakan pembelajaran (Silabus, SAP, Kontrak Perkuliahan), melaksanakan pembelajaran, mengevaluasi pembelajaran dan disiplin dalam mengajar. Hal ini disebabkan beberapa dosen masa kerjanya sudah lebih dari sepuluh tahun, memiliki kompetensi keilmuan dan etos kerja yang tinggi serta usia masih produktif sehingga memungkinkan untuk meningkatkan kinerja. Dalam hal karakter/kepribadian menunjukkan semua dosen baik yaitu kewibawaan sebagai dosen, arif dalam mengambil keputusan, menjadi teladan dalam sikap dan perilaku, mampu mengendalikan diri dalam berbagai situasi dan kondisi serta adil dalam memperlakukan mahasiswa. Untuk nilai terendah, secara umum berada pada aspek kinerja memanfaatkan IPTEK dalam perkuliahan serta inovasi dan kreativitas dalam perkuliahan. Hal ini disebabkan kurangnya penguasaan teknologi serta kurang mengikuti seminar atau diklat untuk peningkatan kompetensi keilmuan dan keahlian.

Kinerja pendidikan dan pengajaran perlu lebih ditingkatkan lagi mulai dari merencanakan pembelajaran, melaksanakan pembelajaran, mengevaluasi pembelajaran, disiplin dalam mengajar serta karakter/kepribadian dosen. Kualifikasi dosen strata dua perlu ditingkatkan ke strata tiga. Beberapa dosen tetap adalah dosen dengan tugas tambahan sehingga ada beberapa yang mengajar tidak sesuai atau melebihi BKD. Untuk itu STA Jember perlu merekrut dosen baru, dengan memerhatikan kualifikasi pendidikan, usia, kompetensi dan etos kerja. 


\section{REFERENSI}

Arikunto, Suharsimi dan Cepi Safruddin Abdul Jabar. 2009. Evaluasi Program Pendidikan Pedoman Teoritis Praktis Bagi Mahasiswa dan Praktisi Pendidikan. Jakarta: PT. Bumi Aksara.

Biro SDM. 2016. Jabatan Karir Dosen. Kemenristekdikti.

Blazey, et al. 2001. Insight to Performance Exellence in Education 2001: An Inside Look at the 2001 Baldridge Award Criteria for Education. Winconsin: ASQ Quality Press.

Buku Pedoman Penilaian Kinerja Dosen Universitas Ngudi Waluyo Tahun 2017.

Chairy, Liche Seniati. 2005. Evaluasi Dosen sebagai Bentuk Penilaian Kerja, Workshop Evaluasi Kinerja Dosen oleh Mahasiswa. Jakarta: UIN Syarif Hidayatullah.

Harisantoso, John. 2012. "Pengukuran Kinerja Dosen Melalui EKD STKIP PGRI Situbondo Berdasarkan Persepsi Mahasiswa.” Jurnal Nasional UMP Sainteks Vol. 9 No. 2, 6471.

Khoirul Maqin. 2016. "Menanam Tri Dharma Perguruan Tinggi” https://www.duniadosen.com

Mangkunegara, A.A. Anwar Prabu. 2017. Evaluasi Kinerja SDM. Bandung: Refika Aditama.

Lepsinger, R., Aanntoinette, D., \& Lucia. 1997. The Art and Science 360 Degree Feedback. San fransisco: Pfifer.

LPM UINAM. 2016. Pedoman Evaluasi BKD UIN Alauddin Makassar. Makasssar: UINAM.

Rismawati dan Mattalata. 2018. Evaluasi Kinerja: Penilaian Kinerja Atas Dasar Prestasi Kerja Berorientasi ke Depan. Makassar: Celebes Media Perkasa.

Simanjuntak, Payaman J. 2011. Manajemen \& Evaluasi Kinerja Edisi 3. Jakarta: Lembaga Penerbit FEUI.

Tim Pengisi Borang. 2018. Buku IIIB Borang Instituti Sekolah Tinggi Alkitab Jember. Jember: STAJ.

Tim Penyusun. 2010. Pedoman BKD dan Evaluasi Pelaksanaan Tridharma Perguruan Tinggi. Jakarta: Dirjen Dikti Depdiknas.

Tim Penyusun. 2012. Statuta Sekolah Tinggi Alkitab Jember. Jember: STAJ.

Tim Penyusun. 2015. Buku Panduan Akademik Sekolah Tinggi Alkitab Jember. Jember: STAJ.

Tim Penyusun. 2017. Pedoman BKD dan Evaluasi Pelaksanaan Tridharma PT Dosen UIN Syarif Hidayatullah Jakarta. Jakarta: Kementerian Agama RI.

Tim Penyusun. 2018. Pedoman Evaluasi Kinerja Dosen. Semarang: Unissula.

Wirawan. 2015. Evaluasi Kinerja Sumber Daya Manusia: Teori, Aplikasi dan Penelitian. Jakarta: Salemba Empat. 